\title{
Technological Forecasting and Social Change
}

Volume 146, September 2019, Pages 181-202

https://doi.org/10.1016/j.techfore.2019.05.014

Accepted 4 May 2019

\section{Evaluating University Industry Collaborative Research Centers}

\author{
Elizabeth Gibson, $\mathrm{PhD}$ \\ University of Colorado, Boulder CO, USA \\ Tugrul U Daim, PhD (*) \\ Portland State University, Portland OR, USA \\ Higher School of Economics, Moscow Russia \\ Chaoyang University of Technology, Taichung, Taiwan \\ Marina Dabic, $\mathrm{PhD}$ \\ Nottingham Trent University, UK \\ and University of Zagreb, Croatia
}

(*) corresponding author: tugrul.u.daim@pdx.edu

Acknowledgements

This research is funded by Science of Science \& Innovation Policy (SciSIP) program at the National Science Foundation (1632908:

Doctoral Dissertation Research) 


\title{
A prior version of this paper was presented at PICMET 2016 conference.
}

\begin{abstract}
This research provides performance metrics for cooperative research centers that enhance translational research through partnerships formed by government, industry and academia. Centers are part of complex ecosystems and vary greatly in the type of science conducted, organizational structures and expected outcomes. The ability to realize their objectives depends on transparent measurement systems to assist in decision making in research translation. We introduce a hierarchical decision model that uses both quantitative and qualitative metrics. A generalizable model is developed based upon program goals. The results are validated through consultation with experts. The method is illustrated using data from the National Science Foundation's industry/university cooperative research center (IUCRC) program. The methodology provides a basis for a generalizable model and measurement system to compares performance of university science and engineering focused research centers supported by industry and government.
\end{abstract}

Keywords: Research and Development Management; Hierarchical Decision Modeling; Industry University Collaboration; National Science Foundation

\section{INTRODUCTION}

Industry-university collaborations conducting multi-disciplinary research are required to solve increasingly complex social problems [1]. Increased U.S. public policy support for initiatives that enhance translational research has resulted in the evolution of many different forms of technology transfer mechanisms [2]. Today, university-based research centers "are prevalent as both policy mechanisms and industry strategies" [[3] pg 76]. Cooperative research centers (CRCs) that involve partnership agreements with actors from three different sectors of government, academia and industry are the most sustainable business models [4]. However, supporting these "triple-helix" [5] or government-university-industry (GUI) [6] collaborations is expensive, driving policy makers to shift their attention towards performance evaluation. 
Academia, policy makers [7] and CRC managers are all invested in understanding the performance and impact of these centers [8]. A wealth of literature examines program evaluation through primarily qualitative case-based methods or quantitative methods based on traditional indicators such as patents and publications. Despite the effort and many excellent studies, researchers are cautioning that traditional measures are inadequate [9], placing a call-to-arms for further research. A multi-dimensional-holistic study with a flexible approach that can evaluate both quantitative and qualitative output indicators is needed. This research begins to fill this gap by presenting a generalizable model for CRC performance evaluation.

The National Science Foundation (NSF) is responsible for technology planning and science and engineering based research and education in the United States. Recognizing the value of industry sponsored cooperative research, the NSF launched a program in 1980 to improve the linkage between industry and university for cooperative research [10]; now known as the Industry-University Cooperative Research Center (IUCRC) program. The success of this model led to the development of other NSF science and engineering centers. Because the model has been replicated multiple times, the social technology clarifies the unit of analysis making it a better candidate for study than other CRCs. Today, over 66 IUCRCs are actively supported by the NSF. Literature shows the IUCRC to be one of the more successful CRCs [11]. Supporting such centers is expensive. So, academia, policy makers and [12] CRC managers are all invested in understanding the performance and impact of these centers [13]. Researchers acknowledge that "the growth in private and public investment in university-based technology initiatives has raised important policy questions regarding the impact of such activities [14][15]. This interest has led to a wealth of literature examining program evaluation through primarily qualitative case-based methods or quantitative methods based on traditional indicators such as patents and publications.

Despite the effort and many excellent studies, researchers are cautioning that traditional measures are inadequate [16], placing a call-to-arms for further research.

This study examines the literature to explore the concerns about current indicators and measurement systems. It adds value by developing a flexible measurement system incorporating qualitative and quantitative metrics. A generalizable model is developed that uses a holistic and 
balanced approach to produce a score that measures effectiveness in which a center is achieving the NSF program's mission. The Wood Based Composites Center illustrates the method using actual center data. Experts validated the methodology and results adding a transparent decision support tool for performance evaluation into the stream of literature.

Including this introduction, the paper is organized into 6 sections. Section 2 reviews the academic literature on national planning of technology and cooperative research center program evaluation. Section 3 describes the research approach and methodology. Section 4 shows how a generalizable hierarchical decision model (HDM) is developed and finalized using expert judgment. Section 5 illustrates and validates the method using actual data collected for a selected IUCRC, discusses the results and summarizes the expert response to the criterion related validation. Finally, section 6 concludes the paper.

\section{LITERATURE REVIEW}

\section{National Technology Planning}

Societal goals change throughout time driving national planning activities and the creation of public policies. Technology foresight is a process that systematically looks into the future to examine areas of research and emerging technologies that can help address changing societal goals. Technology foresight has also been defined as a tool in policy and strategic planning to "wire-up" national innovation programs [17], for priority setting and decision making [18] and for creation of vision and the pursuit of knowledge [19].

Public policy strategies are often the outcome of national foresight activities [20]. Previous to 1980, US policies traditionally focused on facilitating collaboration among industry and academia [21][22]; then the national research agenda shifted to place more focus on technology transfer. Initiatives to facilitate technology transfer have been developed using a variety of different mechanisms that vary in terms of complexity, structure and longevity including: research parks, licensing agreements, R\&D limited partnerships, joint facility use agreements, research institutes, research centers and state-supported science and technology centers. The most sustainable technology transfer mechanisms require industry-sponsored collaborative research [14]

"System changes are labelled 'socio-technical' because they not only entail new technologies, but also changes in markets, user practices, policy and cultural meanings"[23]. Major 
industries such as information and communication technology (ICT)[24], energy[25], food[26], health [27] and transportation [28] are faced with complex socio-technical challenges. Solving environmental problems is a national concern that entails cultural value and belief systems [29]that goes far beyond a technological problem.

\section{Technology Research Centers}

Roessner defines technology transfer as "the movement of know-how, technical knowledge, or technology from one organizational setting to another"[[30] p 31]. The university ecosystem began to change to support technology transfer as evidenced by the creation of technology transfer offices (TTOs) [31] and mission expansion to include entrepreneurial and commercialization statements [32]. Interested in further supportive policies, government started looking for practical organizational structures [33][34] that encouraged knowledge and technology transfer [35] beyond the university sector [36].

Studies provide evidence that public funding of research has had significant impact on CRC programs [37] recording over 27,500 different CRC programs worldwide and thousands in the US alone. A variety of different mechanisms developed that vary in terms of complexity, structure and longevity including: research parks, licensing agreements, R\&D limited partnerships, joint facility use agreements, research institutes, research centers and statesupported science and technology centers.

Figure 1 shows how three of the NSF sponsored CRC programs are positioned in the middle level of performance evaluation problems: materials science and engineering research centers (MRSECs), engineering research centers (ERCs) and industry/university cooperative research centers (IUCRCs). 
Figure 1: CRCs are ecosystems

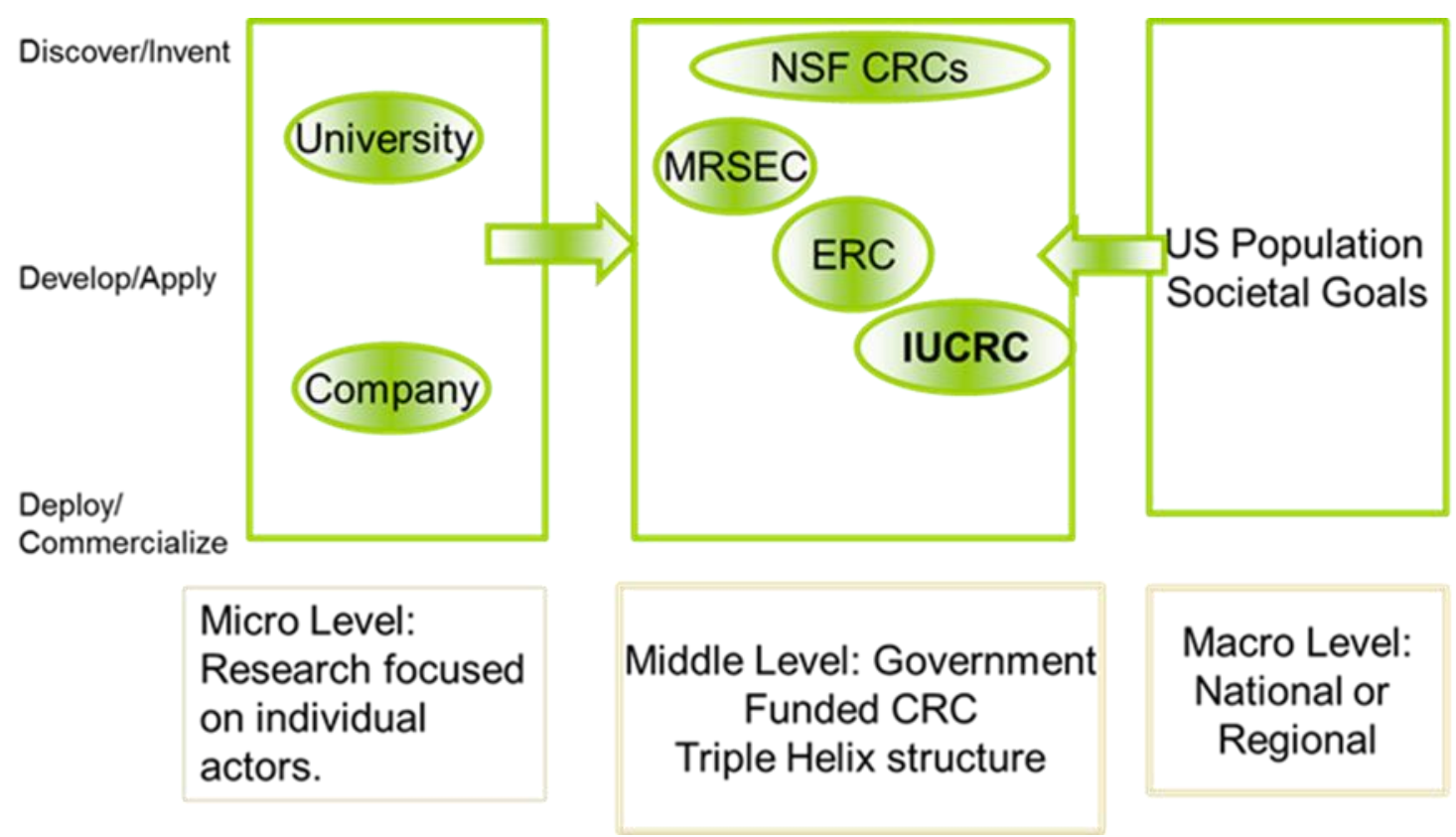

Today, GUI CRC's are a popular mechanism [11][38] for translational research because industry funding is an important business model component for sustainable innovations [39][40]. Bozeman named one stream of literature the "cooperative technology policy paradigm" because it "features an active role for government actors and universities in technology development and transfer" [[41] p 632]. Experts are concerned that "evaluating such centers remains difficult and often subjective, yet federal science agencies continue to invest considerable resources in them." They are resource intensive and financially expensive [42] receiving over $\$ 5$ billion in federal funding [43] for support and evaluation.

Several examples show how policy makers have responded: Passed in 1993, the Government Performance and Results Act requires codification of the use of quantitative metrics for program evaluation [44]. In 2010, the America Competes Act Reauthorization was passed to further support linkages between research investments and economic growth and societal benefits [45].

\section{Evaluation Methods}

The evaluation method literature was synthesized into five [46] groups for further discussion:

1) quantitative econometric and statistical analysis,

2) case-based analysis,

3) social network analysis (SNA), 
4) multiple criteria decision making (MCDM),

5) multi-attribute utility theory (MAUT).

One comprehensive report by Ruegg \& Feller [47] that surveyed evaluation methods and models was particularly useful. The rest of this section reviews the evaluation methods in the literature by the five research method groupings.

Licensing performance is a common theme in the quantitative based literature. For example, Chukumba and Jensen [48], examine how the characteristics of different actors affect licensing performance. Two findings provide evidence of a positive relationship between the importance of venture capital and licensing agreements and that engineering faculty was relatively more important than the other science based faculty. Anderson et. al. used licensing data to examine efficiency [49] and Kim took an in-depth look at the impact of lag time using similar data and metrics. Shane and Somaya[50] use the association of university technology transfer managers (AUTM) association data and patent litigation data to examine the effects on university licensing efforts [51].

The Feldman and Kelly study is different because it uses statistical analysis to test the strength of hypothesized relationships. This method is interesting because it can help to open up the "box" and take a look at the "middle". The survey data was coded as a bi-variate "yes" or "no" then tabulated and tested for statistical significance. Logistic regression was used to test the strength of the relationships [52].

The research method selected for a study depends upon the research problem being investigated and the organizational structure under analysis [53]. These studies are particularly useful at the micro, single-actor level, or macro, total-program level because they use a more consistent method that can be replicated by other researchers to verify and extend the results building convincing evidence about program impacts. These methods are particularly useful to justify the existence of a program and investigate if the total cost of the policy is beneficial to society. Table 1 shows some methods and findings; however, the results don't help to provide comparisons between centers. 
Table $1 \quad$ Quantitative based research in CRC literature

\begin{tabular}{|l|l|l|l|}
\hline Author Year & Purpose & Purpose/ Findings & Method \\
\hline $\begin{array}{l}\text { Cohen, } \\
\text { Florida, Goe }\end{array}$ [54] & $\begin{array}{l}\text { Provide a } \\
\text { comprehensive picture } \\
\text { of IURCs }\end{array}$ & $\begin{array}{l}\text { Measurement of IURC impact } \\
\text { on technology advance }\end{array}$ & $\begin{array}{l}\text { Extensive survey-based } \\
\text { empirical study forming } \\
\text { the "Carnegie Mellon" } \\
\text { database }\end{array}$ \\
\hline $\begin{array}{l}\text { Cohen, Walsh, } \\
\text { Nelson 2002 } \\
\text { 55] }\end{array}$ & $\begin{array}{l}\text { University and } \\
\text { government research } \\
\text { lab contribution to } \\
\text { industrial innovation }\end{array}$ & $\begin{array}{l}\text { System of simultaneous } \\
\text { equations links dependent } \\
\text { variables to firm/industry level } \\
\text { economic variables }\end{array}$ & $\begin{array}{l}\text { Survey-based approach } \\
\text { using Carnegie Mellon } \\
\text { data (1994) hypothesis- } \\
\text { based testing }\end{array}$ \\
\hline $\begin{array}{l}\text { Hall, Link, } \\
\text { Scott 2003 }\end{array}$ & $\begin{array}{l}\text { Investigating roles and } \\
\text { effects of universities in } \\
\text { ATP-funded projects }\end{array}$ & $\begin{array}{l}\text { University involvement may not } \\
\text { speed up commercialization as } \\
\text { partnerships may have more } \\
\text { basic research aspects. }\end{array}$ & $\begin{array}{l}\text { Survey-based study of } \\
\text { ATP-funded research } \\
\text { projects. } \\
\text { Multivariate regression } \\
\text { analysis }\end{array}$ \\
\hline $\begin{array}{l}\text { Chukumba, } \\
\text { Jensen 2005 }\end{array}$ & $\begin{array}{l}\text { Licensing performance } \\
\text { focused at small } \\
\text { business }\end{array}$ & $\begin{array}{l}\text { Licensing by universities with } \\
\text { larger venture capital, } \\
\text { engineering faculty relative high } \\
\text { importance }\end{array}$ & $\begin{array}{l}\text { Empirical, Game theoretic } \\
\text { model, hypothesis testing }\end{array}$ \\
\hline $\begin{array}{l}\text { Feldman and } \\
\text { Kelley, 2006 } \\
\text { [56] }\end{array}$ & Knowledge spillover & $\begin{array}{l}\text { Testing hypothesis for incentive } \\
\text { effects of government R\&D } \\
\text { funding for firms }\end{array}$ & $\begin{array}{l}\text { Empirical survey, 240 } \\
\text { completed, multivariate } \\
\text { regression }\end{array}$ \\
\hline
\end{tabular}

The NSF's Industry-University Cooperative Research Center (IUCRC) program is used as the domain of organizational effectiveness for this research because based upon the longevity and formalized structure of the program. Currently there are 66 centers spanning 175 different university sites [10][42]. In the early 1980s, the NSF concerned about domestic technology transfer [41] formally launched the IUCRC program to improve the linkage between industry and university for cooperative research [10] by transferring "know-how" in the form of organizational structure and best management practices from the NSF to a director and managing research staff.

Using a hybrid organizational structure that allows for flexibility [39], multidisciplinary, research projects are selected by an Industrial Advisory Board (IAB) and conducted collaboratively among university faculty, student researchers and industry partners [57].

IUCRCs may take different forms and vary by participation number and levels, center goals and processes, and outputs [58]. However, there is a formal organizational model with specified policies, processes and procedures for management and evaluation. Table 2 [39] describes the IUCRC model by operational mechanisms and characteristics. 


\section{Table 2 IUCRC characteristics}

\begin{tabular}{|l|l|}
\hline Characteristics & Description \\
\hline Formal membership agreement & Includes unique scope and shared interest agreements \\
\hline Partners & University, industry, other organizations \\
\hline Shared research agenda & Objectives, goals and a roadmap \\
\hline Shared IP & Formal agreement \\
\hline Center Director & Tied to a University [39], diverse [59] \\
\hline Primary Funding Source & Industry members structured min. funding: \$30k from 10 \\
\hline Evaluation & 2x/year reporting, independent formal evaluation \\
\hline Graduate Students & Required involvement \\
\hline Structural Requirements & Funding, organizational, management, reporting \\
\hline
\end{tabular}

Formal partnership agreements are required for membership. These documents include the scope of the research projects and shared interest agreements that help to clarify intent. There are multiple stakeholders that include the NSF, the university, the center director, researchers, students and industry. Formal documents and management practices require regular reports and roadmaps. Other management practices and structural requirements help to establish an IUCRC through its' formation. For example, the funding structure requires that industrial advisory board (IAB) members pay yearly dues.

Performance appraisal is important [60] to the practice of CRC management to understand and maximize the impact of their research findings [61]. According to a White House memorandum [62], funding agencies, academic leadership, and industry must manage their portfolios in an objective, evidence-based manner to address science and technology priorities of our nation and increase the productivity of our research institutions.

The NSF has recognized the importance of a formal evaluation program by continuously supporting a project established at North Carolina State University for the purpose of evaluating IUCRCs. While the evaluation program is structured and formalized with established policies, processes and procedures to address program inputs, activities, outputs, outcomes and impacts, it struggles with some of the same challenges found in literature and is somewhat labor intensive. In a sense, all of the NSF IUCRC program evaluators publish case studies each year for each IUCRC because they use standardized, Level of Interest and Feedback Evaluation (LIFE), forms and questionnaires to collect qualitative data. Table 3 provides an example of some of the cased-based literature focused on IUCRC performance evaluation. 
Table $1 \quad$ Case-based research in CRC literature

\begin{tabular}{|l|l|l|l|}
\hline Author Year & Focus & Findings & Gaps \\
\hline $\begin{array}{l}\text { Gray et. al., } \\
\text { 2003 [63] }\end{array}$ & $\begin{array}{l}\text { IUCRC Evaluation } \\
\text { process }\end{array}$ & $\begin{array}{l}\text { Centers have been extensively } \\
\text { evaluated }\end{array}$ & $\begin{array}{l}\text { Comparative evaluation } \\
\text { missing or of low quality }\end{array}$ \\
\hline $\begin{array}{l}\text { Corley, } \\
\text { Boardman, } \\
\text { Bozeman, 2006 } \\
\text { [64] }\end{array}$ & $\begin{array}{l}\text { Multi-institutional } \\
\text { research evaluation } \\
\text { implications }\end{array}$ & $\begin{array}{l}\text { Need organizational structure or } \\
\text { epistemic development of the } \\
\text { disciplines in the collaborations }\end{array}$ & $\begin{array}{l}\text { More focus needed on the } \\
\text { design of organizational } \\
\text { systems. }\end{array}$ \\
\hline Gray, 2008[43] & $\begin{array}{l}\text { IUCRC Evaluation } \\
\text { Process }\end{array}$ & $\begin{array}{l}\text { Structured case reports needed to } \\
\text { include outcomes, best practices } \\
\text { and breakthrough technologies }\end{array}$ & $\begin{array}{l}\text { Subjective data are non } \\
\text { comparable, coding } \\
\text { methods needed }\end{array}$ \\
\hline $\begin{array}{l}\text { Ramanathan et. } \\
\text { al. 2010 [65] }\end{array}$ & $\begin{array}{l}\text { CETI IUCRC } \\
\text { Stakeholder needs } \\
\text { assessment }\end{array}$ & $\begin{array}{l}\text { Agile design processes benefit } \\
\text { students to span boundaries }\end{array}$ & $\begin{array}{l}\text { Innovation outcomes are } \\
\text { typically unmeasured }\end{array}$ \\
\hline $\begin{array}{l}\text { Scott, 2014 } \\
\text { [66] }\end{array}$ & $\begin{array}{l}\text { IUCRC break- } \\
\text { through } \\
\text { technologies }\end{array}$ & $\begin{array}{l}\text { IUCRCs need a structured way to } \\
\text { report breakthrough technologies }\end{array}$ & $\begin{array}{l}\text { Inconsistency of impact } \\
\text { data. }\end{array}$ \\
\hline
\end{tabular}

Case studies are important because they can paint a detailed story and explain why events are happening tying inputs, activities, outputs and outcomes to impacts. Some of the limitations is the confidentiality of the information or the tendency to under or over report. There is also the problem of comparing centers to one another [66]. It is difficult to generalize from a case study creating opportunity for measurement error.

Social network analysis (SNA) is gaining importance in the literature [5][12]. Several researchers have used SNA methods, tools and techniques to investigate spill-overs [124][125], co-authorship networks [126][80] and membership activity [127]. Structured data such as citations in the scientific databases and filings in patent databases can be mined using bibliometric techniques. Most of the researchers who use the citation of other firms' patents note that patents are not a perfect measure of innovative output [47], because they relate only to codified knowledge and there may be significant differences in patenting behavior between IUCRCs, firms, and technological domains.

However, this method shows promise and researchers are actively working to improve the problem of data availability and linkages. For example, Rafols et al. introduced a new 
method using bibilometric data to map areas of collaboration using network analysis methods [128]. Advances in scientific databases now allow for more sophisticated mapping and the spatial and geographic mapping methods are becoming more popular [129]. A sample of research from leading authors in this area is included in Table 4.

\section{Table $2 \quad$ SNA research in CRC literature}

\begin{tabular}{|l|l|}
\hline Author, year & Topic \\
\hline $\begin{array}{l}\text { Balconi and Laboranti 2006 } \\
\text { [124] }\end{array}$ & $\begin{array}{l}\text { University-industry interactions in applied research: The case of } \\
\text { microelectronics }\end{array}$ \\
\hline $\begin{array}{l}\text { Rafols, Porter, Leydesdorff, } \\
2009 \text { [128] }\end{array}$ & $\begin{array}{l}\text { Science overlay maps: a new tool for research policy and library } \\
\text { management }\end{array}$ \\
\hline Porter Rafols, 2009 [130] & $\begin{array}{l}\text { Is science becoming more interdisciplinary? Measuring and mapping six } \\
\text { research fields over time }\end{array}$ \\
\hline $\begin{array}{l}\text { Abbasi and Altman, 2011 } \\
\text { [125] }\end{array}$ & $\begin{array}{l}\text { Correlation between Research Performance and Social Network Analysis } \\
\text { Measures Applied to Research Collaboration Networks }\end{array}$ \\
\hline Garner et. al. 2012 [131] & $\begin{array}{l}\text { Assessing research network and disciplinary engagement changes } \\
\text { induced by an NSF program }\end{array}$ \\
\hline $\begin{array}{l}\text { Leydesdorff, Carley, } \\
\text { Rafols 2013 [129] }\end{array}$ & Global maps of science based on the new Web-of-Science categories \\
\hline Abassi et. al. 2014 [60] & $\begin{array}{l}\text { Measuring social capital through network analysis and its influence on } \\
\text { individual performance }\end{array}$ \\
\hline
\end{tabular}

Several researchers have used multi-criteria decision making (MCDM) [87] [89] [132] to consider different perspectives in their research. A multi-level decision model (MLDM) is a flexible method that can utilize both structured data and unstructured data by using methods that quantify the expert judgment. Saaty [91] introduced the Analytic Hierarchy Process (AHP), a popular MCDM method to deconstruct a problem into top-down levels of linked concepts. The Hierarchical Decision Model (HDM) is similar to the hierarchical structure of approaching problem and differs in the use of pair-wise comparisons to quantify element weights.

Hierarchical decision models (HDMs) were developed by Phan to evaluate the innovativeness of companies in the semi-conductor industry based upon output indicators [87] and by Tran to develop an index to measure the effectiveness of a technology transfer office (TTO) based upon fulfillment of the stated organizational mission [132]. These researchers measured a broader range of outcomes to include knowledge transfer beyond licensing. In Tran's research, a knowledge and technology transfer effectiveness index was developed to compare 
mechanisms for a particular university. This research is particularly interesting for this study because it provides precedence in the literature for using the HDM as an appropriate methodology as well as additional data to identify knowledge and technology transfer output elements.

The multi-attribute utility theory (MAUT) is another popular multi-criteria model that considers additive value for multiple objectives [133]. Because the AHP and the HDM involve a relative importance assessment procedure and use "a hierarchy to establish preferences and orderings" they are "sometimes classified as a MAUT approach" [[134]p 646]. The MAUT process considers the perspective of a decision maker through the use of utility functions or desirability curves.

Literature clearly documents the importance of CRCs for translational research; but, performance comparison is still somewhat of a challenge [57][67]. Where formal evaluation programs exist, the methods are typically resource intensive with results focused on a single center or at the program level [43]. Table 5 provides evidence for the three leading gaps in the CRC performance evaluation research literature: ecosystem complexity, lack of data, and inadequacy of traditional indicators.

\section{Table 5: Example of performance evaluation challenges found in literature}

\begin{tabular}{|c|c|c|}
\hline Reference & Findings & Theme \\
\hline $\begin{array}{l}\text { Boardman and } \\
\text { Gray, } 2010\end{array}$ & $\begin{array}{l}\text { "CRCs are inherently complex and therefore a challenging } \\
\text { phenomenon to understand". [[1] p 5] }\end{array}$ & Complexity \\
\hline $\begin{array}{l}\text { Roessner,et. al, } \\
2010\end{array}$ & $\begin{array}{l}\text { Lack of a "standardized performance criteria" and "exclusive } \\
\text { reliance on quantifiable data" provides misleading results. [68] }\end{array}$ & $\begin{array}{l}\text { Traditional indicators } \\
\text { inadequate }\end{array}$ \\
\hline $\begin{array}{l}\text { Schmoch et al., } \\
2010\end{array}$ & $\begin{array}{l}\text { "scientific performance should not be measured by a one- } \\
\text { dimensional metric such a publication, since it is a multi- } \\
\text { dimensional phenomenon." [[69] p2] }\end{array}$ & $\begin{array}{l}\text { Traditional indicators } \\
\text { inadequate }\end{array}$ \\
\hline $\begin{array}{l}\text { Palomares- } \\
\text { Montero and } \\
\text { Garcia-Aracil, } \\
2011\end{array}$ & $\begin{array}{l}\text { "It is difficult to obtain valid and reliable data and the results of } \\
\text { evaluation processes depend on the quality of the information } \\
\text { available. There is a lack of disaggregated data to enable } \\
\text { comparison among disciplines, and data often are not sufficiently } \\
\text { firm, resulting in indicators that provide inaccurate results". [[70] } \\
\text { p353] }\end{array}$ & $\begin{array}{l}\text { Lack of available } \\
\text { data, Traditional } \\
\text { indicators inadequate }\end{array}$ \\
\hline $\begin{array}{l}\text { Penfield et. al., } \\
2014\end{array}$ & $\begin{array}{l}\text { "These 'traditional' bibliometrics techniques can be regarded as } \\
\text { giving only a partial picture of full impact with no link to causality. } \\
\text { [61] }\end{array}$ & $\begin{array}{l}\text { Traditional indicators } \\
\text { inadequate }\end{array}$ \\
\hline $\begin{array}{l}\text { Abbasi et al. } \\
2014\end{array}$ & $\begin{array}{l}\text { "Collecting network data has its own limitations" and lack of other } \\
\text { types of data prevents performance comparisons. [[60] p72] }\end{array}$ & $\begin{array}{l}\text { Lack of available } \\
\text { data }\end{array}$ \\
\hline
\end{tabular}


CRC's are complex ecosystems with multiple actors, missions and organizational structures [71]. Basically, "improved methods are needed for program evaluation" [[72] p 11] because a GUI CRC is a complex ecosystem [73]; not a "trivial machine, with a defined inputoutput ratio" [74]. Additional expert input was obtained through a proposal process for this research. Representatives from the NSF Science of Science \& Innovation Policy (SciSIP) program provided additional comments. "Many federal science agencies support large centers of research around a single scientific problem. These centers can vary considerably in the science they support, their structure, and ultimately their strengths. Where one center may make considerable progress in research, another may instead succeed best at producing excellent scientists. Agencies have long struggled with how to evaluate such centers, given their complexity."

While traditional outputs of university research projects such as publications and patents are easily quantified with bibliometrics data, "exclusive reliance on quantifiable data" causes misleading results [68] by painting a partial picture [61]. However, "identifying a set of metrics to evaluate the performance of a university-based ecosystem was [remains] a considerable challenge" [[75] 4]. Thus, the "STI [science and technology] indicators that were important last century may no longer be so relevant today and indeed may even be positively misleading" [[76] p588]. Or worse, are simply the "wrong" metrics [74].

Metrics can be used to compare and differentiate the performance of different organizations. Some organizations produce outputs more efficiently than others or at higher quality levels. Effective use of metrics can help organizations to achieve superior performance outcomes. However, Freeman and Soete argue on the basis of their 40 years of indicators work that "STI [science and technology] indicators that were important last century may no longer be so relevant today and indeed may even be positively misleading" [[76] p588]. Researchers have found that a GUI CRC is a complex ecosystem [73]; not a "trivial machine, with a defined inputoutput ratio" [74]. So, metrics are important; but, which ones are appropriate?

Publications and patents are common outputs of university research projects. Publications typically represent the output of earlier-stage, basic research while patents are typically more indicative of applied research [71]. These traditional outputs are easily quantified with bibliometrics data and have been used in many studies. However, researchers have cautioned that "exclusive reliance on quantifiable data" provides misleading results [68] because they only 
provide a partial picture [61]. Others have cautioned that traditional measures are simply the “wrong” metrics [77][74].

Knowledge transfer and integration also requires understanding of social dynamics and networks. Emerging research in social network analysis and metrics such as betweenness centrality and diversity are promising; but, the use and interpretation is difficult [78]. In a recent, empirical research study involving multiple experts the results concluded that "identifying a set of metrics to evaluate the performance of a university-based ecosystem was a considerable challenge" [[75] 4].

Another group discusses challenges attempting to tie the metrics to the outputs and outcomes because more and better quality data are needed to answer impact type of questions [79]. Some of the available aggregated data was found to be of poor quality leading to inaccurate results [[70]p353]. In general, researchers agree that "due to non-availability of data we are unable to measure" performance of research centers. Researchers are specifically asking for time series membership data [79] and network data [80] that is disaggregated [70].

In summary, performance measurement calls for a comprehensive [81], multi-dimensional approach considering multiple perspectives. This problem requires boundary-spanning criteria because there are many constituent groups who have a stake placing different values on outputs and outcomes. Different perspectives can lead to disagreement about the mission and value of the outputs. For example, different institutional norms govern public and private knowledge [82] [67]. Even when agreement is reached, stakeholder perspectives are expected to shift over time. Literature is calling for more research to examine the effectiveness of the CRC organization and the impact of their activities and outputs [35].

With limited resources, policy makers must be diligent at attempting to make objective and increasingly transparent funding decisions. Despite the importance an increasing investment, a set of holistic output indicators are missing. Missing also are decision support tools and methods to help make performance measurement more cost effective. Without the help of such tools, policy makers are ill equipped to make transparent and objective decisions. They need to know if their program really makes a difference "compared to no program or an alternative one" [[43] $\mathrm{p}$ 78] and how to improve with scarce resources. Therefore this paper adds value to the stream of literature by developing a model that measures the degree to which different science 
and engineering centers meet a program's mission specifications using a balanced set of performance indicators.

\section{METHODOLOGY}

CRC performance should be measured using multi-dimensional criteria because this is a "multi-dimensional phenomenon" [[69] p2]. Understanding that organizational effectiveness is a construct rather than a concept [83] helps to explain why a multi-criteria decision making tool is appropriate for this type of a problem. In the organizational theory literature, Steers [84] and other researchers [85] discuss the importance of using a framework to link decision criteria [86]. Concepts are abstractions defined and measured by characteristics. Higher-level abstractions are often difficult to characterize and measure requiring construction of different concepts.

\section{Multi Criteria Decision Models}

Multi-criteria, multi-level models are useful when decisions are complex and require judgment between multiple alternatives. They present an appropriate method for this study for several reasons:

1) They are flexible, decision support tools that can be used to quantify expert judgment. These methods can handle both qualitative and quantitative data.

2) The hierarchical methods allow for decomposition of a complex decision problem into a hierarchy of smaller sub-problems for independent analysis. The elements of the hierarchy can relate to any aspect of the decision problem under investigation.

3) There is a precedence in the literature. The methods have been used in other research studies to explore complex, multi-dimensional problems [32][87][88][89].

Cleland and Kocaoglu introduced a mission-objectives-goals-strategies-activities (MOGSA), hierarchical decision model (HDM) framework [90] that is well suited for this performance evaluation problem. A key aspect of this method is that the problem can be broken into a hierarchical structure [91], where experts can judge a series of elements in pairwise comparisons. Figure 2 shows how the new model follows the first three levels in the MOGSA framework and replaces the $4^{\text {th }}$ level with measureable outputs. 


\section{Hierarchical Decision Model}

The human brain is designed to analyze complexities by compartmentalizing them and splitting the parts in turn into smaller parts to deal with individually, since it cannot deal with too many factors at the same time. This hierarchical vertical structure is our natural way of thinking. A cross-sectional way of analyzing relations is beneficial when you have a certain objective and want to understand the effect of other factors or the relationship between entities. HDM allows the decision maker to divide the problem into its smaller entities for analysis and therefore reveal any hidden relationship between elements. This methodology has been used for policy planning for a variety of objectives and was proven practical [92] [93] [94] [95] [96].

The other advantage of the HDM is the ability to screen and select a large number of alternatives. Also, a large number of criteria and sub criteria can be used, which allows the analyst to cover the topic under investigation from many different angles. The results of the HDM are not just solid numbers or ranking, this model allows the analyst to dig deep into the results and identify other trends or priorities within the same criteria. This will be of great value for the proposed model since policy analysis is not a binary problem, but needs deep analysis of the integrated relationship among objectives, barriers, and benefits.

This approach will be useful to gain insight into current policies and criteria that are constantly changing with the fast pace of technology development, which is not always accounted for in the literature. This research has utilized the HDM methodology which allows for breaking down the problem into a hierarchical structure in order to analyze the relationship between a mission, objectives, and alternatives (see Figure 2: Generic form of HDM with four decision levels (adopted from 87, 89) 


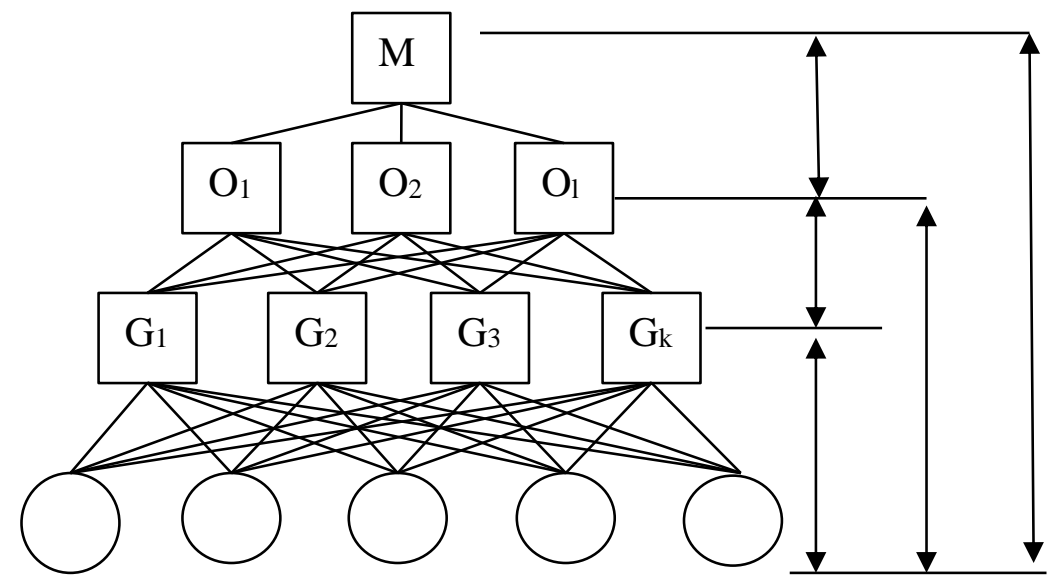

2). HDM is used to quantify expert qualitative judgments and convert them to numerical values using a pair-wise comparison method.

Figure 2: Generic form of HDM with four decision levels (adopted from 87, 89) 


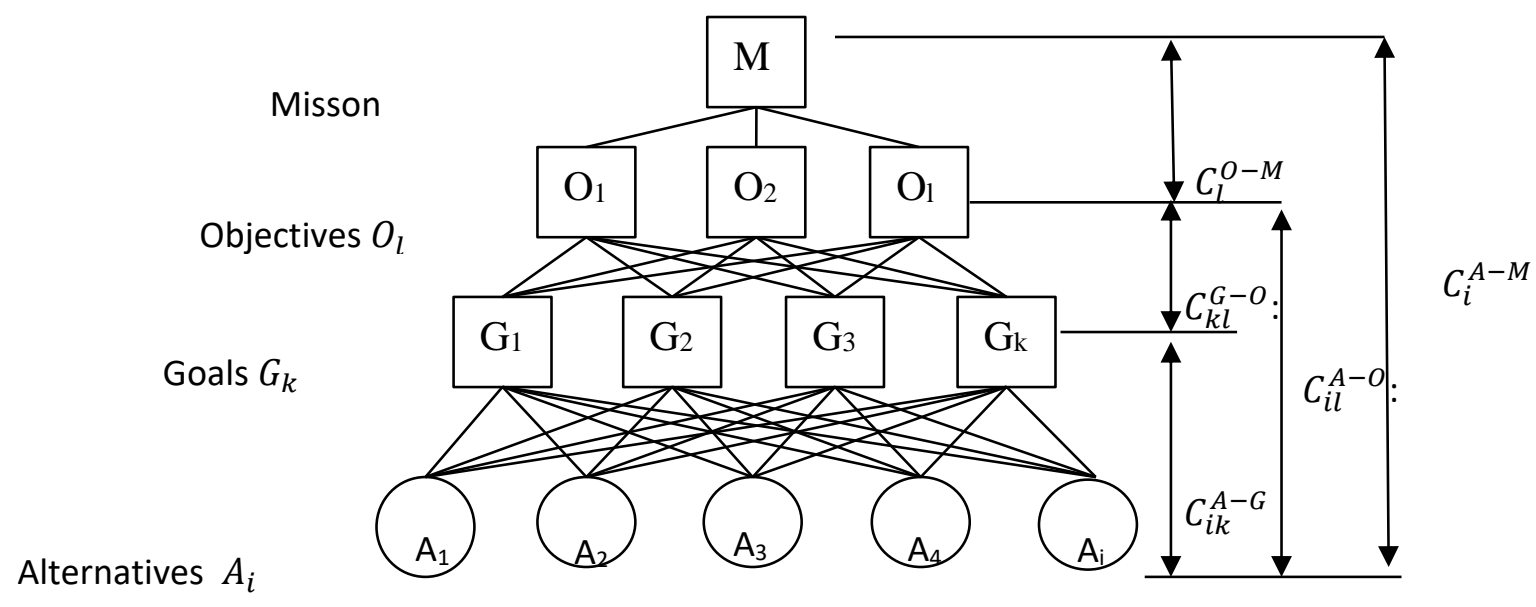

Table 6: Notations for HDM

\begin{tabular}{|c|c|c|}
\hline Where: & & \\
\hline$O_{l}:$ Objectives, l= 1,2,..,l & $\begin{array}{l}C_{l}^{O-M}: \text { relative contribution of the } \mathrm{L}^{\text {th }} \\
\text { objective to the mission }\end{array}$ & \\
\hline$G_{k}:$ Goals, $\mathrm{k}=1,2, \ldots, \mathrm{k}$ & $\begin{aligned} C_{k l}^{G-O}: & \text { relative contribution of the } \mathrm{k}^{\text {th }} \\
& \text { goal to the } \mathrm{L}^{\text {th }} \text { objective }\end{aligned}$ & \\
\hline \multirow[t]{2}{*}{$A_{i}:$ Alternatives, $\mathrm{i}=1,2, \ldots \mathrm{i}$} & $\begin{array}{l}C_{i}^{A-M}: \text { Overall contribution of the } \mathrm{i}^{\text {th }} \\
\text { alternative to the mission }\end{array}$ & $\begin{array}{l}C_{i k}^{A-G}: \text { relative contribution of the } \mathrm{i}^{\text {th }} \\
\text { alternatives to the } \mathrm{k}^{\text {th }} \text { goal }\end{array}$ \\
\hline & & $\begin{array}{l}C_{i l}^{A-O}: \text { relative contribution of the } \mathrm{i}^{\text {th }} \\
\text { alternative to the } \mathrm{k}^{\text {th }} \text { objective }\end{array}$ \\
\hline
\end{tabular}

By using Constant-Sum Method, a total of one hundred points was assigned by experts, divided between any two elements at the same level. For the level of mission (M), quantifying expert judgment relative to the contribution of the objective level to the mission is given as $C_{l}^{O-M}$ (see

Table for all model notations). The overall relative contribution of the energy policy alternative (A) to the mission (M) is calculated by adding the sum products of all local contribution matrices between $\mathrm{M}$ and $\mathrm{A}$ and is given by[97]

$$
C_{i}^{A-M}=\sum_{l=1}^{L} \sum_{k=1}^{K} C_{l}^{O-M} \cdot C_{k l}^{G-O} \cdot C_{i k}^{A-G} \text { Equation } 1
$$

For each level, the judgments were collected and converted to weights. The alternative with the maximum weight sum would be the best "fit" to the mission. Inconsistency and disagreement metrics $[87,89]$ were used to ensure robustness of the model. 


\section{MODEL DEVELOPMENT}

The purpose of the model (decision objective) is placed at the top of the mission-oriented framework. Organizational objectives fill the second level. Goals are placed at the third level and output indicators used to measure the goals fill in the $4^{\text {th }}$ level. Thus, the mission of the model is a performance evaluation score that determines the degree to which objectives measured by a balanced set of output indicators contributes to the IUCRC program's mission.

\section{Figure 3: Generalized hierarchical framework}

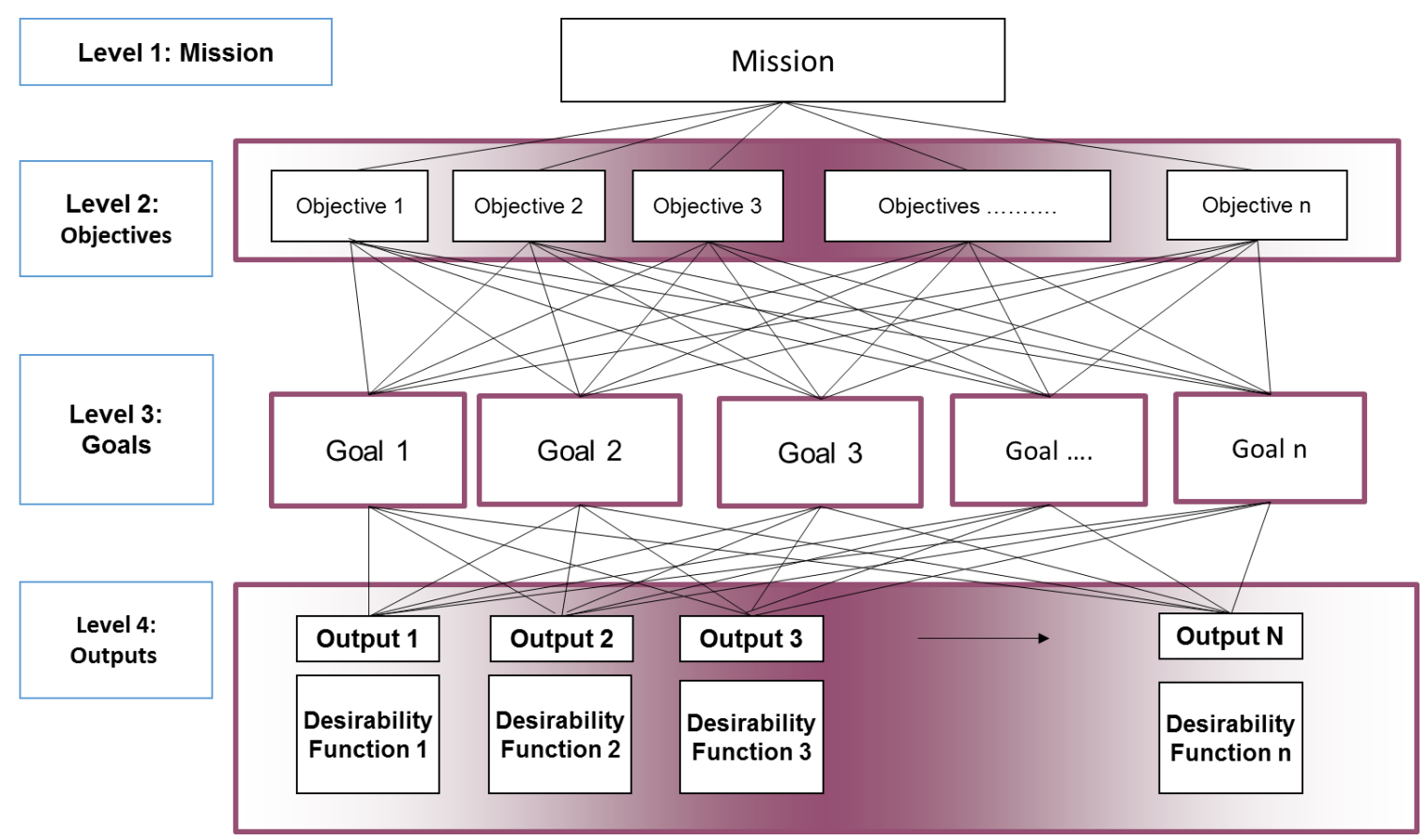

It makes sense that different outputs are not valued the same. Some may contribute to performance more or less than others. The value of relative outputs towards the mission is determined by experts. Mean scores of experts in each panel are then quantified to develop weights for each element. It also makes sense that producing different output quantities meeting different quality standards will provide different results.

Metrics developed for each output are valued using desirability curves. More is not always better and scales are not absolute. Thus, curves reflecting desired output quantity and/or quality are developed. 
Equation 2 shows how a performance effectiveness value (E) can be calculated using multiple criteria (c) for any number of (I) alternatives (a) under comparison.

\section{Equation 2 Performance effectiveness value}

$$
\mathrm{E}\left(\mathrm{a}_{\mathrm{i}}\right)=\sum_{l=1}^{L} \sum_{k=1}^{K} \sum_{j=1}^{J} O_{l} G_{k}^{l} C_{j k}^{k} d(m, j k) \quad \text { for } \mathrm{i}=1, \ldots, \mathrm{I}
$$

Where:

$\mathrm{E}\left(\mathrm{a}_{\mathrm{i}}\right) \quad=\quad$ Effectiveness value for alternative I,

$O_{l} \quad=\quad$ The degree to which objective $\boldsymbol{l}$ contributes towards center performance.

$G_{k}^{l} \quad=\quad$ The relative contribution of goal $\boldsymbol{k}$ under objective $\boldsymbol{l}$ towards performance.

I $=\quad$ Number of alternatives under comparative evaluation,

$\mathrm{J} \quad=\quad$ Number of outputs,

$\mathrm{K}=\quad$ Number of goals,

$\mathrm{L} \quad=\quad$ Number of objectives,

$\mathrm{d}\left(m_{i}, j k\right)=\quad$ Metric desired value of alternative $(i)$ for $j$ th criterion under goal $(k)$,

$\boldsymbol{C}_{j k}^{k} \quad=\quad$ Relative importance of criterion $(j k)$ under goal $(k)$.

\section{Expert Panels}

Expert judgment is a key component in this research approach. Experts validated the linked model elements for content and construct. Expert panels were formed to collect data. After completing data analysis for consistency and disagreement, the accepted data was used to quantify decision element weights finalizing the model. Consultation with experts validated the results and the generalizability of the model. Appendix 1 shows the details on the experts used.

This study uses a two-phased research design where thirty-seven selected experts were formed into five (5) different panels to validate then quantify decision elements. Several experts met the criteria for multiple panels and were motivated to participate on them. Experts in the sixth panel were asked to validate and quantify desired metrics.

Expert numbers were assigned in order that consent forms were received. Many of the experts have multiple titles. The title column is not a complete representation of an expert's experience as many experts fill multiple roles. The primary background qualifying the expert for the study was classified as a regular or contracted employee of the NSF (NSF), a leading researcher (R), or a center director, co-director or executive (C).

Each panel was configured to consider a balanced perspective to minimize bias and encourage a richer and more diverse pool of data Column 1 in Figure 4 shows how the thirty-seven (37) 
experts were configured into six (6) panels. Columns 2 and 3 discuss how experts were asked to validate and quantify different levels of decision criteria.

Figure 4 Panel configurations

\begin{tabular}{|c|c|c|c|c|}
\hline ID \# & $\begin{array}{l}\text { Phase } 1(\mathrm{P} 1) \text { : Validate } \\
\text { content and construct. }\end{array}$ & $\begin{array}{l}\text { Phase } 2 \text { (P2): Data } \\
\text { collected to quantify } \\
\text { elements. }\end{array}$ & $\begin{array}{l}\text { Expert Panel } \\
\text { Qualifications }\end{array}$ & $\begin{array}{l}\text { Research Instruments and Data Collection } \\
\text { Methods }\end{array}$ \\
\hline $\begin{array}{l}1 \\
P 1(2) \\
P 2(1)\end{array}$ & $\begin{array}{l}\text { Validation of construct } \\
\text { and content of level } 2 \text { : } \\
\text { political. }\end{array}$ & $\begin{array}{l}\text { Quantification of } \\
\text { objectives at the political } \\
\text { level of the model. }\end{array}$ & $\begin{array}{l}\text { NSF IUCRC directors } \\
\text { (past/present) NSF IUCRC } \\
\text { Project Director }\end{array}$ & $\begin{array}{l}\text { Phone Interview: open- ended and closed- } \\
\text { ended questions for quantification and } \\
\text { qualitative contextual data later used for } \\
\text { scenario analysis }\end{array}$ \\
\hline $\begin{array}{l}2 \\
P 1(9) \\
P 2(8)\end{array}$ & $\begin{array}{l}\text { Validation of construct } \\
\text { and content at the } \\
\text { organizational level. }\end{array}$ & $\begin{array}{l}\text { Quantification of goals at } \\
\text { the organizational level } \\
\text { of the model. }\end{array}$ & $\begin{array}{l}\text { NSF IUCRC program } \\
\text { evaluations. Leading researchers } \\
\text { in the field. }\end{array}$ & \multirow{4}{*}{$\begin{array}{l}\text { Four instruments were developed for each } \\
\text { panel group for phase } 1 \text { (P1) to validate } \\
\text { elements respective to each groups } \\
\text { perspective. Another set of instruments were } \\
\text { developed for phase } 2 \text { (P2) to extract pair- } \\
\text { wise comparison data for quantification } \\
\text { P1) Binary checklist (agree/ disagree) with } \\
\text { open text box for additional qualitative data. } \\
\text { P2) Survey requesting pair-wise comparisons } \\
\text { with drop-down box allowing for numerical } \\
\text { selection of values [1,99]. }\end{array}$} \\
\hline $\begin{array}{l}3 \\
\text { P1(8) } \\
\text { P2(14) }\end{array}$ & $\begin{array}{l}\text { Validate sub-criteria } \\
\text { outputs relative to } \\
\text { parent goals. }\end{array}$ & $\begin{array}{l}\text { Quantify outputs relative } \\
\text { to goals characterizing } \\
\text { objective } 1 \text { (research). }\end{array}$ & $\begin{array}{l}\text { NSF evaluation members, } \\
\text { Leading researchers }\end{array}$ & \\
\hline $\begin{array}{l}4 \\
P 1(11) \\
P 2(13)\end{array}$ & $\begin{array}{l}\text { Validate sub-criteria } \\
\text { outputs relative to } \\
\text { parent goals. }\end{array}$ & $\begin{array}{l}\text { Quantify outputs relative } \\
\text { to goals characterizing } \\
\text { objective } 2 \text { (students). }\end{array}$ & $\begin{array}{l}\text { NSF IUCRC Center directors } \\
\text { (past/present), Leading } \\
\text { researchers }\end{array}$ & \\
\hline $\begin{array}{l}5 \\
\text { P1(9) } \\
\text { P2(15) }\end{array}$ & $\begin{array}{l}\text { Validate sub-criteria } \\
\text { outputs relative to } \\
\text { parent goals. }\end{array}$ & $\begin{array}{l}\text { Quantify outputs relative } \\
\text { to goals characterizing } \\
\text { objective } 3(\mathrm{KTT}) \text {. }\end{array}$ & $\begin{array}{l}\text { Leading researchers, Center } \\
\text { directors/co-directors, IAB } \\
\text { Members, KTT experts }\end{array}$ & \\
\hline $\begin{array}{l}6 \\
\text { P1(4) } \\
\text { P2(4) }\end{array}$ & $\begin{array}{l}\text { Validate metrics and } \\
\text { data sources available } \\
\text { for desirability curves. }\end{array}$ & $\begin{array}{l}\text { Quantify "goodness" } \\
\text { data to develop } \\
\text { desirability curves. }\end{array}$ & $\begin{array}{l}\text { NSF Evaluators, leading authors } \\
\text { respective to perspective: coop. } \\
\text { research, IUCRC student, or KTT. }\end{array}$ & $\begin{array}{l}\text { Phone Interviews: Acceptance of metric and } \\
\text { context, subjective data to qualify statements } \\
\text { for quantification of desirability values. Email. }\end{array}$ \\
\hline
\end{tabular}

For example, experts in panel 2 validated and quantified goals relative to each of the three (3) objectives. Qualifications for each of the panels and the data collection methods used are also discussed. Separate judgment quantification instruments were created for each of the functions: validation, quantification and desirability curve development. The expert panel formation process also considered how different perspectives are required at three (3) different levels.

Table 7 shows how expert judgement is an appropriate method to validate the model content, construct and results [[32]p71].

\section{Table $7 \quad$ Summary of evaluation tests}

\begin{tabular}{|l|l|l|}
\hline Validity & What is measured & Methods \\
\hline Construct & $\begin{array}{l}\text { The degree to which a measure relates to } \\
\text { expectations formed from theory for } \\
\text { hypothetical construct }\end{array}$ & $\begin{array}{l}\text { Judgmental, } \\
\text { Correlation, } \\
\text { Convergent-discrimination } \\
\text { Factor analysis } \\
\text { Multitrait-multimethod }\end{array}$ \\
\hline Content & $\begin{array}{l}\text { Degree to which the content of the items } \\
\text { adequately represents the universe of all } \\
\text { relevant items under study }\end{array}$ & Judgmental \\
\hline $\begin{array}{l}\text { Criterion- } \\
\text { related }\end{array}$ & $\begin{array}{l}\text { Degree to which the criterion can capture the } \\
\text { true value of the variable }\end{array}$ & $\begin{array}{l}\text { Judgmental, } \\
\text { Correlation }\end{array}$ \\
\hline
\end{tabular}




\section{Model Components}

The hierarchical decision model (HDM) provides a flexible, hierarchical structure for decision analysis. The purpose of the model is to determine the degree to which an IUCRC meets the program's mission. It is a generalizable model that outputs a performance evaluation score for an IUCRC in the program by evaluating a holistic set of metrics.

At the top of the model, the objective is the organizational effectiveness score. At level 2, the NSF IUCRC program objectives specify the mission of the program.

Literature finds the NSF IUCRC program's mission, outlined in what has become known as "the purple book" [39], is specified by three objectives:

1. To pursue fundamental (collaborative and pre-competitive) engineering and scientific research having industrial relevance.

2. To produce graduates who have a broad, industrially oriented perspective in their research and practice.

3. To accelerate and promote the transfer of knowledge and technology between university and industry (public) ([39]p 23).

The objectives are placed at the second level of the model as shown in figure 5.

Figure 5: NSF IUCRC program objectives 


\section{Objectives}

\begin{tabular}{|c|}
\hline Level 2: \\
NSF IUCRC \\
program \\
objectives
\end{tabular}
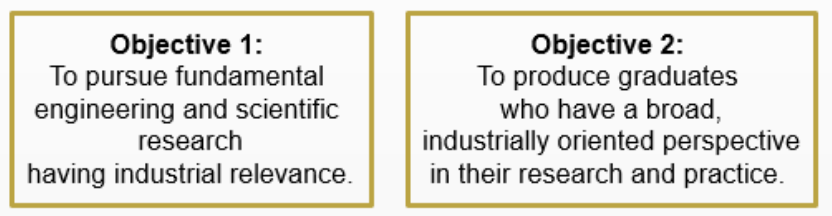

Collaborative focus has increased as demonstrated by recent incentives for multi-partner sites (Gray et. al. 2011).

Pre-Competitive refers to research conducted jointly by usually competing firms (Perkman et. al. 2010). Industrial relevance must address opportunities and problems important to

Stakeholders

(Hevner et. al., 2003).

\section{Objective 3: \\ To accelerate and promote the transfer of knowledge and technology between university and industry}

Knowledge and technology transfer is a complex construct that spans boundaries with many definitions (Comacchio et. al. 2011).

Knowledge transfer is often indirect (Link, 2002)

The NSF has taken "knowledge transfer" out of the objectives on their official website

(www.nsf.iucrc/about)

The development of collaborative, pre-competitive research has been a part of the program's mission since inception [39]. Thus, key to the program is promoting boundary spanning activities through cooperative partnerships and multi-disciplinary science [98]. Since the early 1990's, the IUCRC solicitations have increased incentives for multi-site IUCRCs [99]. The minimum threshold for a multi-site proposer is $\$ 350 \mathrm{~K}$ while single-site membership requires $\$ 400 \mathrm{~K}$ per year. A program expert confirmed that a lower threshold for multi-site membership agreements will likely continue.

An IUCRC requires graduate student involvement [39]. Funding and scholarships provide graduate students opportunities to complete research towards a thesis or dissertation making programs more attractive [100]. Students gain experience and acquire knowledge through a cooperative and industry-oriented approach to conducting research.

Knowledge and technology transfer (KTT) is a complex construct, spanning boundaries [101] with many definitions. The facilitation of knowledge and technology transfer [5] is key to achieving the NSF IUCRC's mission as stated in the third objective: to accelerate and promote the transfer of knowledge and technology between university and industry [[39] p23] that benefits the public [102][68][103]. 
Each of the three objectives are further characterized by two measurable goals. "New knowledge" and "stakeholder satisfaction" measure how fundamental research is pursued and how satisfied stakeholders are with this pursuit. Producing graduates requires involved students and a strong development program. The goals used to characterize KTT are based on Bozeman's "Contingent Effectiveness Model of Technology Transfer" [[41] p 637]. Figure 6 shows how two goals are linked to each of the three objectives and how the Bozeman model is adapted for this research.

\section{Figure 6: Goals}

\section{Goals}
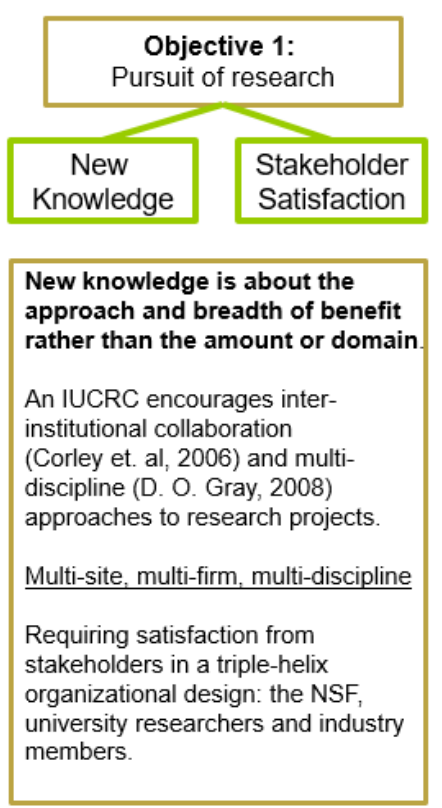

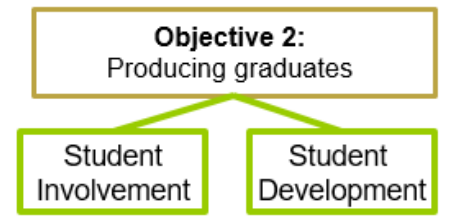

An IUCRC requires graduate

involvement. (Gray and Walters, 1998)

Opportunities for graduate students to complete research towards a thesis or

dissertation is another important aspect

of an IUCRC (Behrens and Gray, 2011).

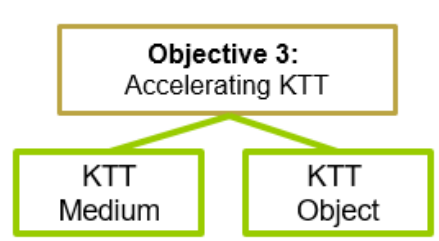

"Contingent Effectiveness Model of Technology Transfer" classifies knowledge and technology transfer (KTT) into media and objects (Bozeman, 2000).

\begin{tabular}{|l|l|l|}
\hline Dimension & IUCRC Focus & Description \\
\hline Transfer agent & $\begin{array}{l}\text { The IUCRC seeking to transfer the } \\
\text { technology. }\end{array}$ & $\begin{array}{l}\text { University partners and IAB member } \\
\text { firms are joined through contractual } \\
\text { agreements to form an IUCRC. }\end{array}$ \\
\hline $\begin{array}{l}\text { Transfer } \\
\text { medium }\end{array}$ & $\begin{array}{l}\text { The vehicle, formal or informal by } \\
\text { which the technology is transferred. }\end{array}$ & $\begin{array}{l}\text { Person-to-person, formal literature, } \\
\text { copyright, license, CRADAs, etc. }\end{array}$ \\
\hline $\begin{array}{l}\text { Transfer } \\
\text { object }\end{array}$ & $\begin{array}{l}\text { The content and form of what is } \\
\text { transferred, the transfer entity. }\end{array}$ & $\begin{array}{l}\text { New methods, new processes, } \\
\text { technological devices, know-how and } \\
\text { specific characteristics of each. }\end{array}$ \\
\hline $\begin{array}{l}\text { Transfer } \\
\text { recipient }\end{array}$ & $\begin{array}{l}\text { The organization or institution } \\
\text { receiving the transfer object. }\end{array}$ & $\begin{array}{l}\text { IAB member firm, public, other IUCRC } \\
\text { partners }\end{array}$ \\
\hline $\begin{array}{l}\text { Demand } \\
\text { environment }\end{array}$ & $\begin{array}{l}\text { Domain factors pertaining to the } \\
\text { need for the transferred object. }\end{array}$ & $\begin{array}{l}\text { Interest in technology, market price } \\
\text { for technology, substitutability, etc. }\end{array}$ \\
\hline
\end{tabular}

It is important to carefully select outputs [104] that not only "fit" the mission specifications but are also aligned with the social technology characterizing the NSF IUCRC program. Experts provided qualitative input regarding the ability of decision elements obtained from the literature review to represent the uniqueness of the NSF IUCRC program. Then, experts judged each element providing quantitative binary acceptance data using a Delphi process. Elements were accepted when an $80 \%$ agreement level was reached by the panel of experts [32]. The validated model is shown in figure 7 and used to guide this discussion. 
Figure 7: Validated model construct

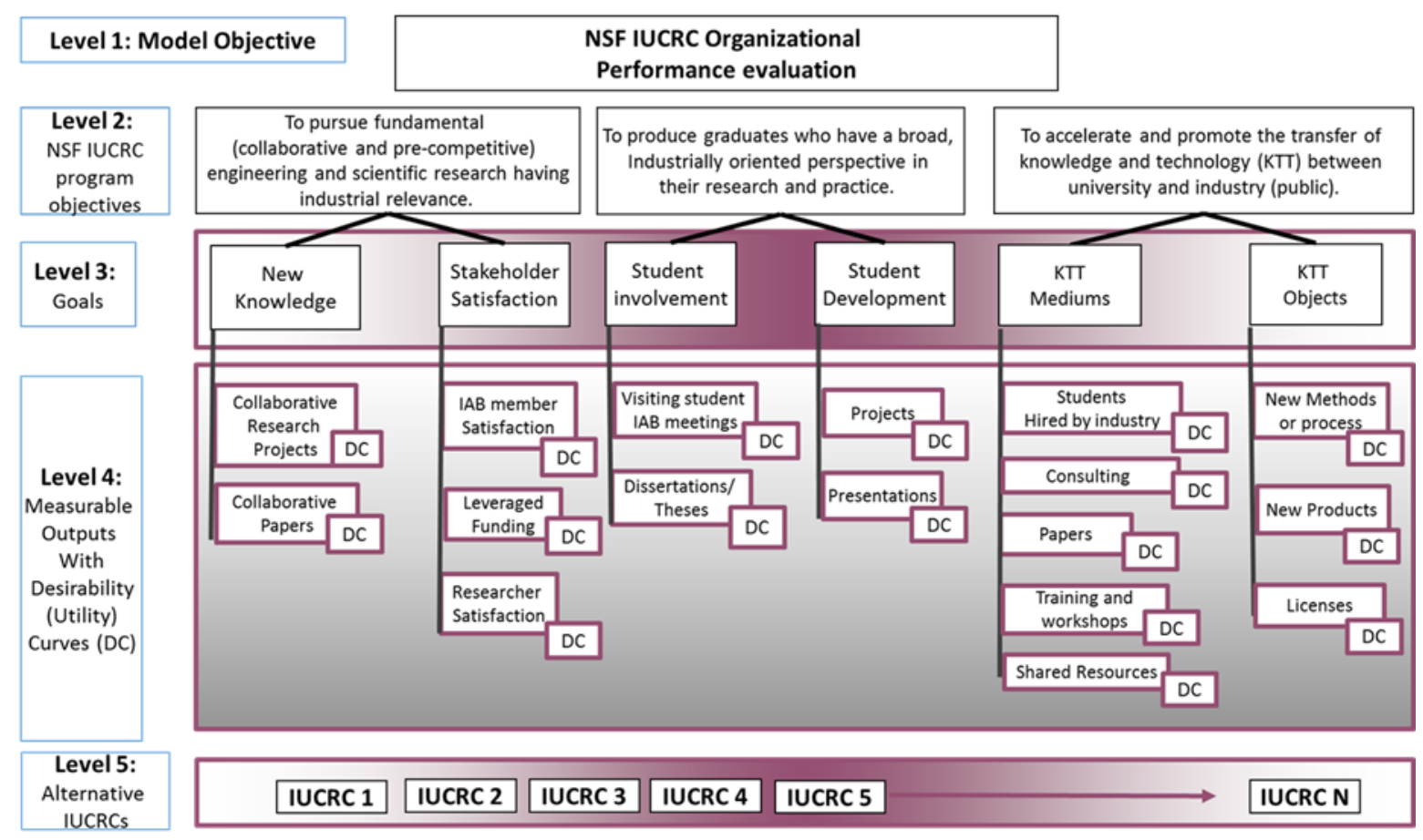

Literature documented outputs for new knowledge generated through multi-disciplinary and multi-site collaboration are summarized in Table 8 . Through the validation process, experts clarified that "patents are explicitly NOT a part of the IUCRC program" because they discourage pre-competitive research.

Table $8 \quad$ Literature identified new knowledge outputs

\begin{tabular}{|l|l|l|}
\hline New Knowledge & IUCRC focused description & Reference \\
\hline $\begin{array}{l}\text { Scientific Co- } \\
\text { publications }\end{array}$ & $\begin{array}{l}\text { Co-authorship. The IUCRC literature } \\
\text { emphasizes authors to be affiliated with } \\
\text { different organizations. }\end{array}$ & $\begin{array}{l}{[21][38][40][41][42]} \\
{[43][44][48][51]}\end{array}$ \\
\hline $\begin{array}{l}\text { Patents and co- } \\
\text { patenting }\end{array}$ & Multiple firms listed as owners. & {$[17][37][40][41][43]$} \\
\hline $\begin{array}{l}\text { Collaborative } \\
\text { research projects }\end{array}$ & $\begin{array}{l}\text { Researchers affiliated with multiple } \\
\text { organizations. Multi-disciplinary research has } \\
\text { been recently emphasized in the IUCRC and } \\
\text { team science literature. }\end{array}$ & $\begin{array}{l}{[5],[37][38][40][41][43]} \\
{[45][50][51][53][59]}\end{array}$ \\
\hline
\end{tabular}

In an IUCRC there are three primary stakeholder groups: government, university and industry. The satisfaction of each group must be considered; however, this is somewhat of a challenge because often there are competing needs. For example, researchers seeking tenure may be motivated to publish and become frustrated if an IAB member lobbies for publication to be 
delayed. Some IAB members may be short sighted and not appreciate the nature of precompetitive research, instead being more focused on solving an immediate problem facing their company. Industrial advisory board (IAB) members can be satisfied in an IUCRC that is not performing well if they are getting more benefit from the research. So, it is important to consider the trade-offs among the three primary stakeholder groups.

There was some debate about student involvement, participation and engagement at IAB meetings. Some IAB meetings have allowed members to attend using electronic communications. With advances in today's communication technologies such as video conferencing, some consider remote attendance at meetings as sufficient. However, researchers have found the value of long-distance participation to be limited [98].

While literature identifies many different outputs for student development such as: number of courses taken, number of degrees earned, number of projects completed, papers written and presentations given; the IUCRC program is focused on research and presentations. Students will receive degrees whether they conduct industry-related research or not.

Bozeman describes a KTT medium as the vehicle, formal or informal by which the technology is transferred [41]. KTT media supported by literature include personnel exchanges, demonstrations, papers and professional networks. Shared knowledge and idea generation [99] transferred at networking and informal events are difficult to evaluate often using attendance and participation as proxy measures. Knowledge generation and knowledge transfer is evaluated differently. When students, faculty or industry members conduct research they are creating knowledge whereas when they are teaching or taking a course they become containers for knowledge. Table 9 summarizes KTT media sources defined in the literature.

KTT objects provide the form and document the content of what is transferred. Some examples of this transfer entity include new products or services, new methods or processes and patents. In an IUCRC, focus is placed on a technological breakthrough or advance such as: "significant process improvements, new process or techniques, and new or improved products or services that resulted either directly from, or was indirectly stimulated by the center's research program" (Scott, 2014). The NSF has published a set of Compendiums that catalogue peer reported breakthrough technologies. Table 10 identifies KTT objects found in literature. 


\section{Table $9 \quad$ Literature identified KTT media}

\begin{tabular}{|c|c|c|}
\hline KTT media & IUCRC focused description & References \\
\hline Papers & $\begin{array}{l}\text { Publications in peer-reviewed journals are } \\
\text { traditionally recognized outputs of KTT. }\end{array}$ & $\begin{array}{l}\text { [21] [38] [40] [41] [42] [43] [44][48] } \\
{[51][105][106][107][108]}\end{array}$ \\
\hline Reports & Research reports & {$[44][51]$} \\
\hline $\begin{array}{l}\text { Conference } \\
\text { presentations }\end{array}$ & & $\begin{array}{l}{[5][38][40][42][43][44][45]} \\
{[51][53][54]}\end{array}$ \\
\hline Workshops, classes & $\begin{array}{l}\text { Attendance at IUCRC directors meetings and } \\
\text { IAB meetings, workshops. }\end{array}$ & $\begin{array}{l}{[2][5][44][45][67][53][55]} \\
{[109][105][100]}\end{array}$ \\
\hline Informal meetings & $\begin{array}{l}\text { Informal meetings, one-on-one discussions } \\
\text { or small informal groups }\end{array}$ & [38] [41] [42] [44] \\
\hline $\begin{array}{l}\text { Professional } \\
\text { networks: Editors, } \\
\text { Professional } \\
\text { Organization } \\
\text { officers, Boards }\end{array}$ & $\begin{array}{l}\text { Editorships and members in scientific } \\
\text { advisory boards and officers of professional } \\
\text { organizations improve linkages and the } \\
\text { profile of the organization. Editors often find } \\
\text { knowledgeable referees who agree to review } \\
\text { papers, officers organize conferences and } \\
\text { meetings. }\end{array}$ & $\begin{array}{l}{[110][43][51][53][69][10]} \\
{[105][111][112]} \\
{[113][114]}\end{array}$ \\
\hline $\begin{array}{l}\text { Graduate hires, } \\
\text { fellowships }\end{array}$ & Graduates hired into the industry & $\begin{array}{l}{[5][38][40][41][43][44][48][50]} \\
{[53][58][59]}\end{array}$ \\
\hline Co-supervising & $\begin{array}{l}\text { Supervisors from multiple sites or multiple } \\
\text { organizations }\end{array}$ & [38] [40] [43] [45] \\
\hline Personnel exchange & Focus on student internships, mentorships. & $\begin{array}{l}{[10][41][43][44][51][53][54]} \\
{[41][53][115][55][116]} \\
{[32][117][118]}\end{array}$ \\
\hline Consulting services & $\begin{array}{l}\text { Secondary focus on scientific faculty } \\
\text { contracted by IAB member firm to facilitate } \\
\text { commercialization of technology. }\end{array}$ & $\begin{array}{l}\text { [5] [37] [38] [41] [42] [43] [44] } \\
\text { [45] [46] [53] [54] }\end{array}$ \\
\hline Shared resources & $\begin{array}{l}\text { Examines not only alternative uses of } \\
\text { resources but also possible impacts on the } \\
\text { mission such as improved human capital for } \\
\text { conducting future research }\end{array}$ & $\begin{array}{l}{[38][43][44][53]} \\
{[119][106][98][120]}\end{array}$ \\
\hline
\end{tabular}

\section{Table $10 \quad$ Literature identified KTT objects}

\begin{tabular}{|l|l|l|}
\hline KTT Objects & IUCRC focused description & References \\
\hline Licenses & $\begin{array}{l}\text { Traditional indicators long used in the literature to } \\
\text { measure technology transfer. Often an indicator of } \\
\text { intent to commercialize the technology. }\end{array}$ & $\begin{array}{l}{[17][37][40][41][43]} \\
{[44][46][50][51][54]} \\
{[56][59]}\end{array}$ \\
\hline New products & $\begin{array}{l}\text { Focus on pre-competitive and collaborative. Beneficial } \\
\text { to industry (beyond 1 company) Compendium of } \\
\text { breakthrough technologies compiles a list of new } \\
\text { products and methods by IUCRC [121]. }\end{array}$ & {$[5][10][57][122]$} \\
\hline $\begin{array}{l}\text { New methods or } \\
\text { procesess }\end{array}$ & & \\
\hline
\end{tabular}

Table 11 shows how metrics are used to describe each output. The parent element for each output is a relative goal that is identified in column 1 . 


\section{Table $11 \quad$ Output decision elements with metrics}

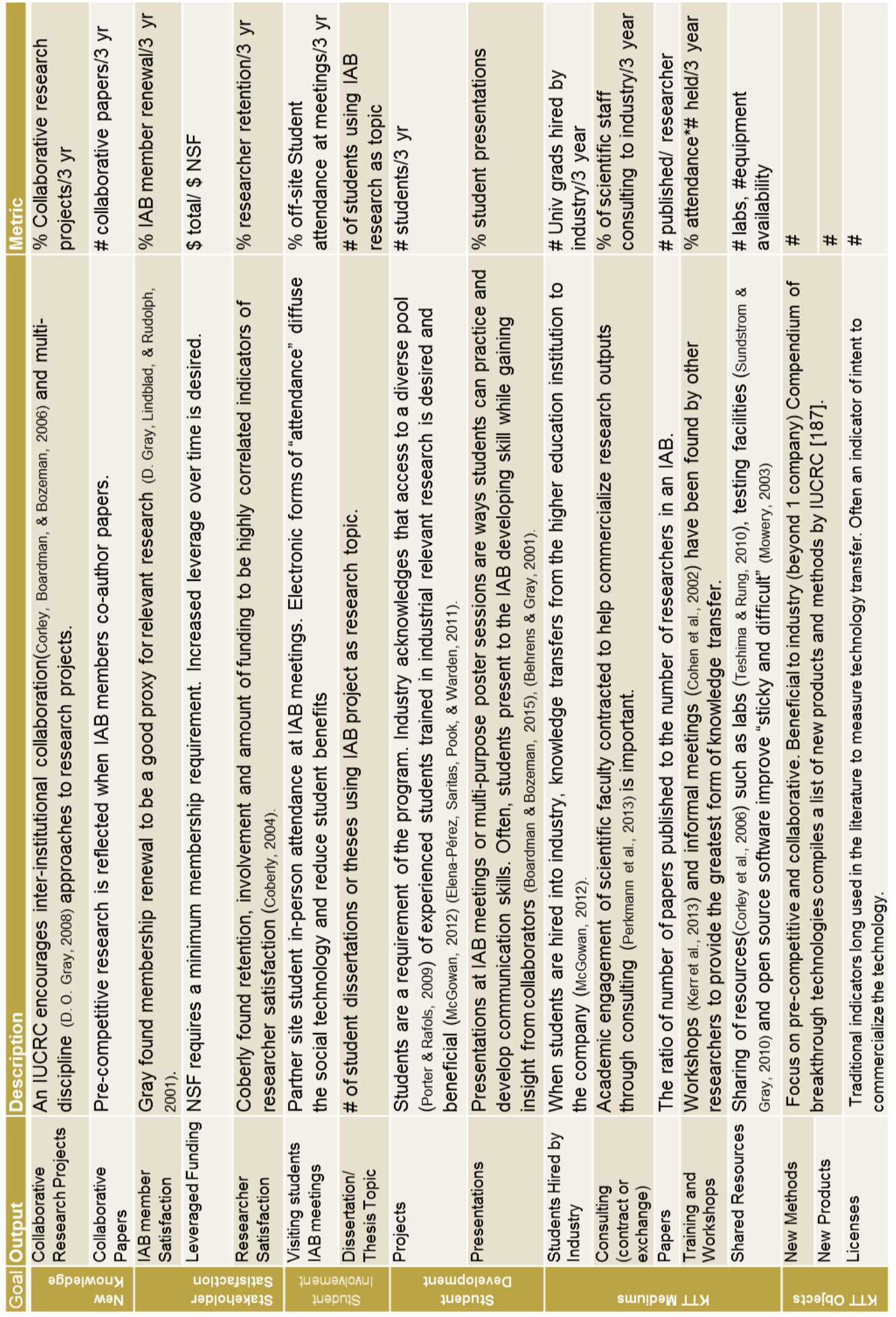


Development of a desirability curve is a method to convert either qualitative or quantitative data used for measuring a decision element to a scaled quantitative value. Understanding the desired or ideal value for a metric is important. The relationship of values for different metrics may scale differently. Comparing desired values against a consistent scale normalizes the values.

So, what value is desirable for each of the outputs? In a complex ecosystem, stakeholders may provide conflicting judgment about these values. For example, IAB membership renewal rates are used to measure $\mathrm{IAB}$ member satisfaction. If experts agree that some turn-over is normal and a desired retention is $80 \%$ or better, $40-50 \%$ retention may or may not be judged to be half as good. A $60 \%$ retention may signify a tipping point or problem.

\section{Final Model}

Figure 8 shows the model quantified through the expert panels with HDM. This model was applied to a case study in the next section

\section{Figure 8 Generalized HDM for IUCRC performance evaluation}

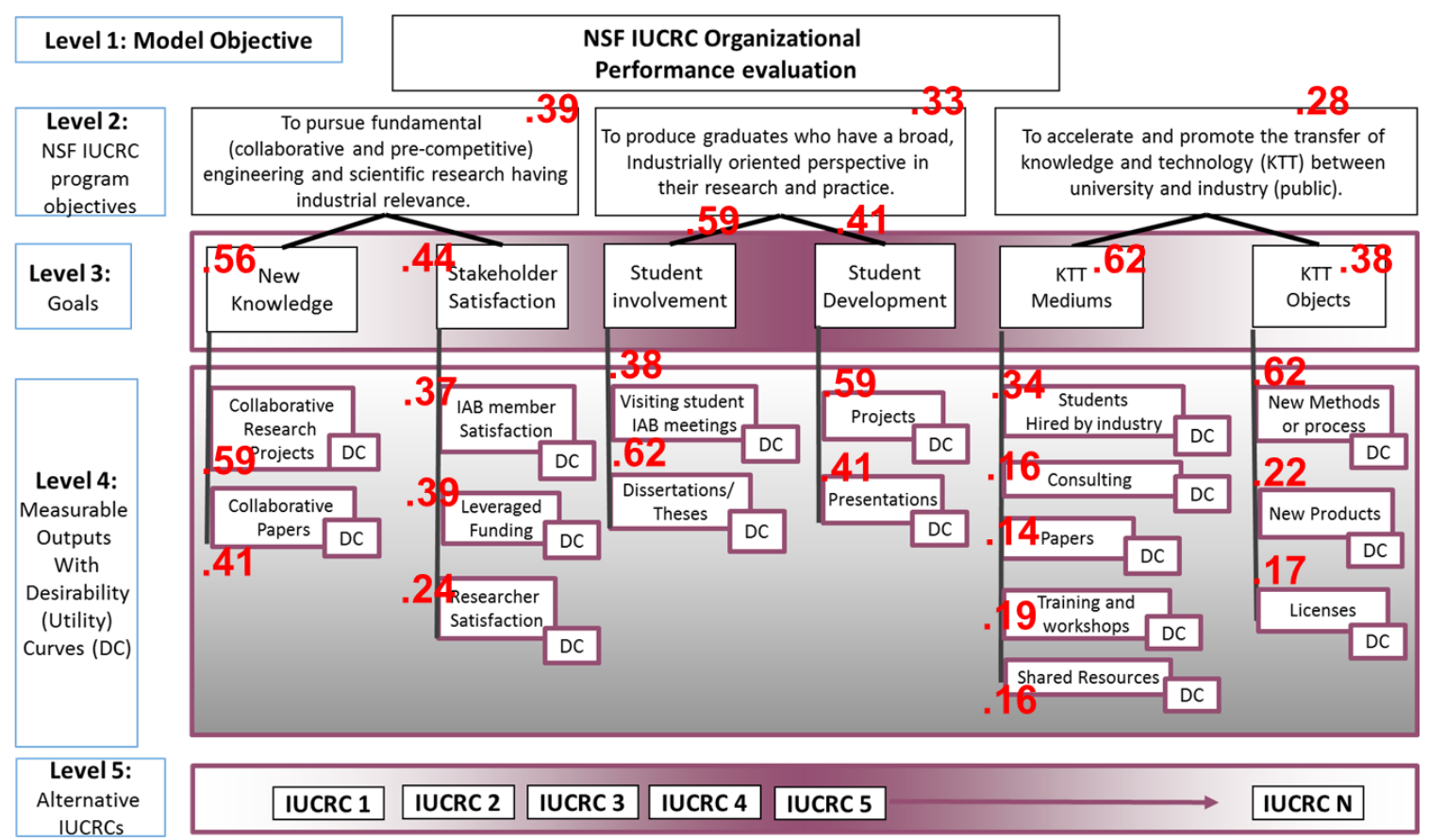




\section{CASE STUDY APPLICATION}

A case study is developed to illustrate how the model works and to conduct criterionrelated validation. Criterion-related validation enlists the help of an expert to evaluate the degree to which the model reflects actual performance. Data collected for the Wood Based Composites (WBC) center was used to populate the metrics, find respective desirability values and calculate a score. Consultation with experts validated the results and generalizability of the model.

\section{Case Study Background}

The mission of the Wood-Based Composites Center (WBC) (Figure 7) is to advance the science and technology of wood-based composite materials. While the center was formed with only 2 partner universities, it has grown to informally include four more. On their website (wbc.vt.edu) the center discusses goals that include attracting students to careers in the woodbased composites and adhesion industries by providing "intellectual exchange and interaction among professionals and students."

Data was collected from five secondary data sources: center websites, NSF IUCRC structural information reports, center minutes, the NSF Compendium of Breakthrough Technologies and the ProQuest and interviews. Information about collaborative projects and background information on researchers and configurations of projects was obtained from specific IUCRC websites. From the NSF IUCRC evaluation program database, structural information reports from 2010 - 2014 were used for most of the descriptive statistics. Data regarding attendance was collected from the NSF evaluator. The Compendium of Breakthrough Technologies provided data regarding new methods and processes. The ProQuest database was searched to identify theses and dissertations published by students with advisors affiliated with IUCRC research projects. A content analysis was conducted on the abstract and the acknowledgement section of each identified student thesis or dissertation to ascertain if the research topic was aligned with an IAB research topic.

Figure 7 Wood-Based Composites Center 


\section{WW: Wood-Based Composites Center}

Their mission is to advance the science and technology of wood-based composite materials.

15 Industry Member Companies

10 Research Faculty

23 Student Participants (2013-2014 structural report)

2 University Partners

4 Other Participating Universities

wbc.vt.edu
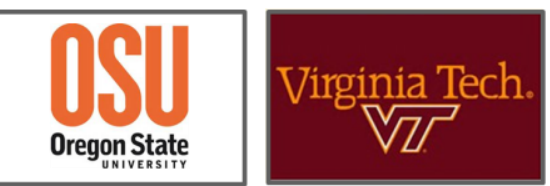
UBC
UNE
BRIVERSITY OF
BRITH
COLUMBIA

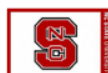

\section{Data Collection}

The next step is to populate each metric with the data. A metric $(m)$ for an output criteria $\left(c_{j}\right)$ under the jth goal with respect to the kth objective can be represented as $\left(m_{W B C}, j k\right)$. The metric for collaborative papers is used to illustrate how the data from the NSF database can be collected to obtain an actual value. Equation 2 uses data collected from the last three available NSF Structural Information (SI) reports to calculate the number of renewed IAB memberships. Equation 2 IAB member renewal

$$
I A B \text { member renewal }=(\text { \# members starting }-\# \text { of members left })
$$

Equation 3 uses this formula to calculate a metric value for IAB member satisfaction using the percent of members who renew.

\section{Equation 3 Percent member renewal}

$$
\begin{gathered}
\% \text { member renewal }=(\# \text { IAB member renew }) /(\# \text { starting }) \\
(m, \% \text { member renewal })=\frac{\left[\left(\frac{8}{8}\right)+\left(\frac{8}{9}\right)+\left(\frac{9}{11}\right)\right]}{3} * 100=90.2 \%
\end{gathered}
$$

The results of the data collection for each metric, $(m, j k)$, are presented in Table 12 . The metric and its relative $j$ th criterion are identified in the first two columns followed by the resulting value obtained from the listed data source. 
Table 12

Metric values for WBC test case

\begin{tabular}{|c|c|c|c|c|}
\hline$j$ & Metric & Value & Data Source & Approach used \\
\hline 1 & $\%$ collaborative projects & .33 & $\begin{array}{l}\text { Center website } \\
\text { wbc.vt.edu }\end{array}$ & $\begin{array}{l}\text { Current number of collaborative project } \\
\text { configurations/Total number of projects listed }\end{array}$ \\
\hline 2 & $\begin{array}{l}\text { \# of collaborative } \\
\text { papers }\end{array}$ & 0 & $\begin{array}{l}\text { NSF } \\
\text { www.ncsu.edu/ } \\
\text { iucrc/ }\end{array}$ & $\begin{array}{l}\text { Average number of collaborative papers } \\
\text { published as recorded } / 3 \text { years }\end{array}$ \\
\hline 3 & $\%$ IAB member renewal & .90 & NSF & $\begin{array}{l}\text { Calculated } 3 \text { year average using (members } \\
\text { renewed)/ } \\
\text { members starting }\end{array}$ \\
\hline 4 & Leverage funding ratio & 3.83 & NSF & $\begin{array}{l}\text { Calculated } 3 \text { year average using total } \\
\text { funding/NSF IUCRC funding }\end{array}$ \\
\hline 5 & $\begin{array}{l}\% \text { research faculty }(\mathrm{RF}) \\
\text { change }\end{array}$ & 1.11 & NSF & $\begin{array}{l}3 \text { year average change for Current number } \\
\mathrm{RF} / \text { past year number RF }\end{array}$ \\
\hline 6 & $\begin{array}{l}\text { \% student meeting } \\
\text { attendance }\end{array}$ & .33 & $\begin{array}{l}\text { NSF IUCRC } \\
\text { evaluator }\end{array}$ & $\begin{array}{l}\text { Averaged for } 2 \text { IAB meetings (\# non-site } \\
\text { students/\# total non-site students) }\end{array}$ \\
\hline 7 & $\%$ students topics & 0 & ProQuest database & $\begin{array}{l}3 \text { year average (\# dissertations or theses } \\
\text { published/\# students) }\end{array}$ \\
\hline 8 & $\begin{array}{l}\text { Student supervision } \\
\text { ratio }\end{array}$ & 1.2 & NSF & Calculated 3 year average students/RF \\
\hline 9 & $\%$ Students presented & 0.14 & $\begin{array}{l}\text { NSF IUCRC } \\
\text { evaluator }\end{array}$ & \# students who presented/\# students \\
\hline 10 & \# Students hired & 2 & NSF & 3 year average students hired \\
\hline 11 & $\%$ RF contracts & 0.07 & NSF & $\begin{array}{l}3 \text { year average RF contracts using in-kind } \\
\text { personnel support }\end{array}$ \\
\hline 12 & \# Papers published & 0.63 & NSF & 3 year average papers published/researcher \\
\hline 13 & $\begin{array}{l}\text { \% RF meeting } \\
\text { attendance }\end{array}$ & 8.87 & $\begin{array}{l}\text { NSF IUCRC } \\
\text { evaluator }\end{array}$ & $\begin{array}{l}2 \text { mtg. average: \# RF attending IAB meeting/\# } \\
\text { total RF }\end{array}$ \\
\hline 14 & $\begin{array}{l}\text { Shared resources } \\
\text { available }\end{array}$ & Both & NSF & $\begin{array}{l}\text { Binary “yes/no" availability of facilities or } \\
\text { equipment }\end{array}$ \\
\hline 15 & $\begin{array}{l}\text { \# New Methods or } \\
\text { Processes }\end{array}$ & 1 & NSF Compendium & \# reported in recent past Compendium \\
\hline 16 & \# New Products & 0 & NSF Compendium & \# reported in recent past Compendium \\
\hline 17 & \# New Licenses & 0 & NSF evaluator & $\begin{array}{l}\text { Calculated proxy: Dependent value based upon } \\
\text { new products }\end{array}$ \\
\hline
\end{tabular}

The value of each metric $(m, j k)$ is standardized using a desirability function. The illustration for the percent of IAB member renewal is continued to show how a desirability curve can be used to standardize a value $\mathrm{d}(m, j k)$, for each respective decision criteria. Figure 9 shows how the calculated value of a $90 \%$ renewal rate is very close to a value $100 \%$ desired by the experts. In fact, it is closer to $100 \%$ than if every member had renewed. Experts expect some turn-over because some smaller companies are sponsored by the SBIR program. While it may be concerning when larger long-term IAB members do not renew, turn-over of smaller SBIR sponsored organizations is desired. Equation 10 shows how the desired value for WBC's membership satisfaction rate ( $c 3$ ) relative to the goal of stakeholder satisfaction ( $g 2)$ is $d\left(m_{W B C}\right.$, $\left.c_{3,2}\right)=.97$. Appendix 2 lists all the desirability curves 
Figure 9 WBC value for \% membership renewal results

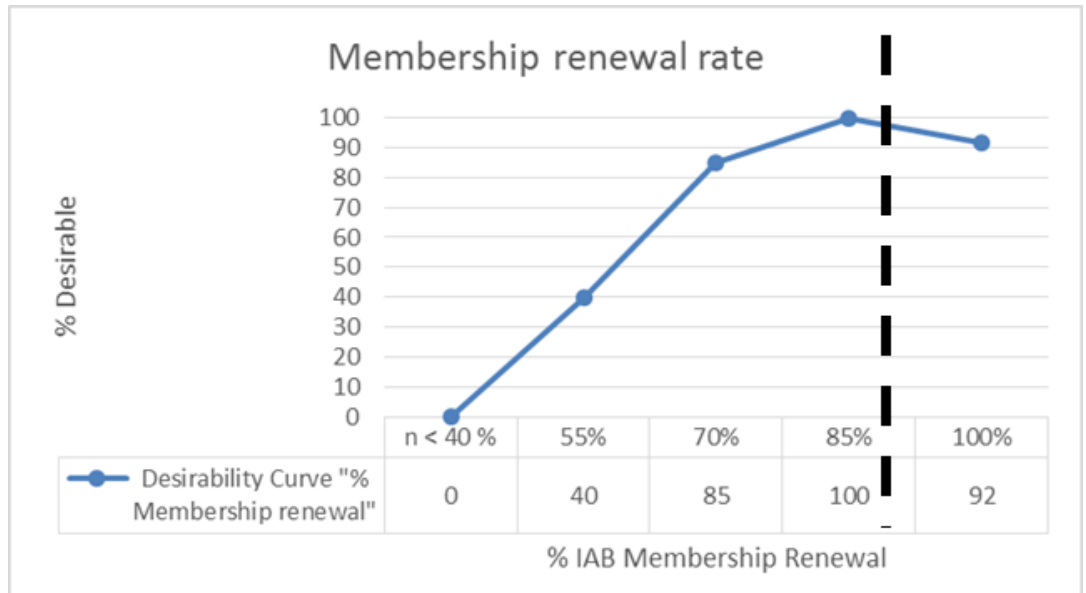

Equation 4 Desirability value for membership renewal

$\frac{92-100}{100-85}=\frac{x}{90}, \quad x=-4.8 \quad 92 \%-(-4.8 \%)=96.8 \%$

\section{Results}

Populating the rest of the metrics with data yields the desirability values recorded in table 13 .

Table 13 WBC Metrics and desirability values

\begin{tabular}{|l|c|c|}
\hline Output decision element & Metric Value $(\boldsymbol{m}, \boldsymbol{j k})$ & $\begin{array}{c}\text { Desirability curve value } \\
d(\mathrm{~m}, j k)\end{array}$ \\
\hline Collaborative Projects & 0.33 & 0.28 \\
\hline Collaborative Papers & 0.00 & 0.00 \\
\hline IAB Member Satisfaction & 0.90 & 0.97 \\
\hline Leveraged Funding & 3.83 & 0.70 \\
\hline Researcher Satisfaction & 1.11 & 1.00 \\
\hline Student Mtg. Attendance & 0.52 & 0.73 \\
\hline Student Research Topic & 0.00 & 0.03 \\
\hline Student Research Project & 1.20 & 0.75 \\
\hline Student Presentations & 0.14 & 0.25 \\
\hline Student Hires & 2.00 & 1.00 \\
\hline Consulting & 0.07 & 0.37 \\
\hline Papers Published & 0.63 & 0.80 \\
\hline Training and Workshops & 0.69 & 0.75 \\
\hline Shared Resources & Both & 1.00 \\
\hline New Methods or Processes & 1.00 & 1.00 \\
\hline New Products & 0.00 & 0.50 \\
\hline Licenses & 0.00 & 0.50 \\
\hline
\end{tabular}


A final score can be calculated by summing the product of the values found for each

$d(m, j k)$ and the decision element's $\left(C_{j k}^{k}\right)$ weight $\left(w_{j}\right)$. Equation 5 shows the expression used to calculate the sum the products of the two vectors.

\section{Equation 4 Performance evaluation score$$
\sum_{j=1}^{17}\left[w_{j} * d(m, j k)\right]
$$

Table 14 reflects the results of applying the expression identified in equation 5.

Table $34 \quad$ Calculated Performance Evaluation Score

\begin{tabular}{|l|c|r|r|}
\hline Output Contribution & Weights & \multicolumn{1}{l|}{$d(m, j k)$} & \multicolumn{1}{c|}{ Product } \\
\hline C. Research Projects & 0.14 & 0.28 & 0.039 \\
\hline C. Research Papers & 0.08 & 0.00 & 0.000 \\
\hline IAB Member Sat & 0.06 & 0.97 & 0.058 \\
\hline Leveraged Funding & 0.07 & 0.70 & 0.049 \\
\hline Researcher Sat. & 0.04 & 1.00 & 0.040 \\
\hline Visiting Students & 0.07 & 0.73 & 0.051 \\
\hline Student Topics & 0.12 & 0.03 & 0.004 \\
\hline Student Projects & 0.08 & 0.75 & 0.060 \\
\hline Student Presentations & 0.05 & 0.25 & 0.012 \\
\hline Student Hires & 0.06 & 1.00 & 0.060 \\
\hline Consulting & 0.03 & 0.37 & 0.011 \\
\hline Papers & 0.02 & 0.80 & 0.016 \\
\hline Training and Workshops & 0.04 & 0.75 & 0.030 \\
\hline Shared Resources & 0.03 & 1.00 & 0.030 \\
\hline New Methods/Proc. & 0.07 & 1.00 & 0.070 \\
\hline New Products & 0.02 & 0.50 & 0.010 \\
\hline Licenses & 0.02 & 0.50 & 0.010 \\
\hline Sum of the Product & & & 0.550 \\
\hline
\end{tabular}

The shaded values represent the higher weighted decision elements. While this model has seventeen decision criteria notice how the top 2 account for $26 \%$ of the performance 
contribution. This means the decision criteria are not linearly related and that the method is able to separate more important elements from the ones that contribute towards the organizational performance to a lesser degree.

Outputs contributing most to this center's performance include research that translates into new methods, engaged students presenting on research and satisfied NSF and IAB member stakeholders. Areas identified for improvement include the number of graduates selecting IAB research topics for their PhD dissertations or Master's theses and more collaboratively configured research project teams.

The data for this center shows there were no theses or dissertations published by students using topics from the IAB center during the last 3 years of data. The desired value for no publications is 0.03 versus a score of 0.42 for a center with an average of 1 publication/year. The result of encouraging students to use center topics for their $\mathrm{PhD}$ dissertation research or Master's Thesis would reflect 5\% increase in total performance contribution. On the other hand, increased emphasis, expenditure in time and resources on improving licensing would only improve the score by $1 \%$.

An example of how a reasonable set of actions could impact the overall performance of the WBC to the IUCRC program's mission is provided in table 15. Note how encouraging students to select IAB topics for their dissertation or thesis could gain the center a $5 \%$ increase in overall performance.

\section{Table $45 \quad$ Performance improvement recommendations}

\begin{tabular}{|l|l|l|l|l|l|l|}
\hline Center & \multirow{2}{*}{$\begin{array}{l}\text { Pre- } \\
\text { Score }\end{array}$} & $c_{j}$ & Suggested Improvement & \multicolumn{2}{|l|}{ Contribution } & New \\
\cline { 4 - 6 } & & & & Current & Impact & Score \\
\hline WBC & 0.55 & 1 & $\begin{array}{l}\text { Encourage 1 student to select an IAB } \\
\text { research project as their dissertation or thesis } \\
\text { topic. }\end{array}$ & 0 & +.05 & 0.65 \\
\cline { 3 - 5 } & 2 & Projects 4/14 increase to 70\%. & .05 & +.05 & \\
\hline
\end{tabular}

As shown, a strength of the model is that the more important decision criteria can be identified and their impact can be analyzed relatively quickly. This can be a powerful aid to managers and policy makers because transparency can lead to better decisions. The model was sued for another 5 centers and recommendations for them are listed in Appendix 3 
First, experts validated the model's content and construct through a structured Delphi process. Next, expert review of the case study results determined that the model is appropriate and generalizable. Table 16 summarizes how the research design used expert judgment to evaluate results for content validity, construct validity and criterion-related validity.

\section{Table $56 \quad$ Validation results}

\begin{tabular}{|l|l|l|l|}
\hline $\begin{array}{l}\text { Research } \\
\text { Validation }\end{array}$ & $\begin{array}{l}\text { Test description for this } \\
\text { research }\end{array}$ & Methods & Results \\
\hline $\begin{array}{l}\text { Content } \\
\text { Validity }\end{array}$ & $\begin{array}{l}\text { The degree to which the } \\
\text { content adequately } \\
\text { describes the NSF IUCRC } \\
\text { mission. }\end{array}$ & $\begin{array}{l}\text { Delphi process during model } \\
\text { development. Experts } \\
\text { validated content and } \\
\text { construct when 80\% } \\
\text { agreement was reached. } \\
\text { Criteria and linked } \\
\text { relationships were validated } \\
\text { [32]. }\end{array}$ & $\begin{array}{l}\text { Experts validated 17 of the } \\
\text { decision criteria identified } \\
\text { by literature. }\end{array}$ \\
\cline { 3 - 4 } & $\begin{array}{l}\text { Elements linked together } \\
\text { creating the logic in a } \\
\text { hierarchical construction. }\end{array}$ & $\begin{array}{l}\text { Proxy metrics developed } \\
\text { for several indicators for } \\
\text { lack of data. }\end{array}$ \\
\hline $\begin{array}{l}\text { Criterion- } \\
\text { related }\end{array}$ & $\begin{array}{l}\text { Degree to which the } \\
\text { criterion can capture the } \\
\text { true value of the IUCRC's } \\
\text { performance. }\end{array}$ & $\begin{array}{l}\text { Expert review of case study } \\
\text { analysis and results. }\end{array}$ & $\begin{array}{l}\text { Experts were in general } \\
\text { agreement with the results } \\
\text { from the case study and } \\
\text { determined the model is } \\
\text { appropriate and } \\
\text { generalizable. }\end{array}$ \\
\hline
\end{tabular}

Experts validated the decision criteria and relative linkages for seventeen elements when an $80 \%$ agreement level was met [32]. At level 2 in the HDM, the first objective was changed to emphasize that fundamental research is collaborative and pre-competitive. While the objectives were accepted with these minor changes, experts revealed a healthy level on-going debate about the third objective, knowledge and technology transfer. This objective has been narrowed on the NSF's website lending more emphasis towards direct commercialization by removing the word "knowledge." However, this focus shift is not supported in the current literature stream or by the experts in this study. Rather, literature emphasizes the importance of knowledge and technology transfer because indirect transfer is often overlooked [123].

In discussing the weighted values of the output decision elements, one expert shared they have "been concerned for some time about the over emphasis of using licensing and papers as indicators." Specifically, several experts stressed that "knowledge and technology transfer is not about the short-term gain of licenses or products developed by one firm, it's really about the long term impact of students who make their career in the field." This research supports this viewpoint. For example, a large amount of time and resources spent on acquiring additional 
licenses would not make as much impact on a center's performance score as encouraging more students towards theses or dissertation topics related to IUCRC research projects.

Experts were not surprised that student topics contributed a high degree towards student involvement. "Students who are more involved typically have a personal motive and interest beyond the research project. It's the students who are willing to work at home, continuing to conduct research that are the most engaged." Some students working as research assistants participate in the center as more of a job.

Experts believe a significant role can be played by university graduates hired into the field and by new methods for accelerating and promoting knowledge and technology transfer. These results make sense because graduates have the opportunity to provide a long term impact to the field. This perspective was supported by the judgment provided by the expert panels reflected in student hires contributing approximately $6 \%$ towards the mission. As shown, a strength of the model is that the more important decision criteria can be identified and their impact can be analyzed relatively quickly. This can be a powerful aid to managers and policy makers. However, what happens to the model when experts disagree about the decision criteria? This model and these values are subjective and not absolute. There are many reasons for differences. Some centers may have more difficulty with intellectual property issues because of their technology domain; they may instead focus on development of students. Efforts such as these could be diminished with this pure benchmarking approach.

The inconsistency and disagreement analysis provided new insights. For instance, one expert argued the fairness of one indicator: "Inclusion of a metric for student hires may be problematic because there is a high percentage of International students." Therefore, some IUCRCs may have participating students who are legally not able to accept a position in a company if one was extended. They further qualified their argument expressing concern about possible screening practices that could be encouraged as a result of too much focus in this area. While the expert data uncovered some findings that may be of interest to policy makers and NSF IUCRC directors, a debate about the mission or objectives of the NSF program is beyond the scope of this reserch. Instead the goal here has been to measure the degree to which centers are meeting the mission as currently defined.

The metric measuring collaborative research also had a high amount of disagreement. Some experts advocated for only counting multi-site or multi-disciplined configured research 
teams, others stated that all were collaborative by definition because they had industry sponsorship. In general, all experts agree that "collaborative projects is probably one area that has not be given enough focus."

The Wood-Based Composites IUCRC was used to illustrate how a performance evaluation score is calculated using the model. One strength of the model is that decision criteria contributing to a higher degree towards the organizational performance can be readily identified. The case showed how improvement in outputs for the more heavily weighted decision elements could significantly improve performance.

The results and generalizability of the model was validate through consultation with experts. Experts expressed interest for a broadened study that examined how to make the model even more generalizable.

\section{CONCLUSIONS}

This research was able to successfully meet the original objectives set forth at the beginning of this paper. While this research was successful at taking a step towards closing the gaps identified in the literature, many still remain. Limitations included use of subjective data, development of proxy metrics and partial data sets. Future research opportunities are plentiful in this area including extensions to other NSF and NIH CRC and other types of CRC programs, methods for more robust sensitivity analysis, longitudinal studies to examine possible forecasting models for program sustainability and integration with proposal evaluation studies.

Increasingly important is the need for inter-disiplinary and inter-organizational

collaborative research. Recognizing this need, the US National Science Foundation (NSF) has responded with funding and programmatic support for cooperative science and engineering research centers (CRCs). While evidence shows these centers are effective mechanisms for fundamental research, student development and knowledge and technology transfer; challenges remain to effectively measure and compare the performance of these organizations.

Organizational effectiveness is a difficult construct. Using the HDM, concepts were identified, validated by experts and linked together to construct a generalizable model. Transparency in how the decision variables impact the final performance scores was demonstrated 
by analyzing how a center could turn their performance upside-down by focusing on fewer than $20 \%$ of the outputs. Understanding where to shift resources can be a powerful decision aid to center directors. In one case example, it was demonstrated how the WBC center could obtain a significant performance increase by re-configuring project teams to include multi-disciplinary researchers and advising students towards completion of dissertation or theses using IAB projects as topics.

Centers were comparatively analyzed providing specific recommendations. The results were presented to an expert for criteria-related validity. The expert review validated the model and the results. The generalizability of the model was validated for the IUCRC program and interest was expressed for a broadened study to make the model even more generalizable.

\section{Research Contributions}

This research begins to fill some of the gaps identified in literature. First, a system of outputs and metrics were presented from a balanced perspective. The hierarchical decision model (HDM) was introduced as a measurement system using both quantitative and qualitative metrics. The holistic study was validated using a 3-phased validation approach: 1) concept and content validation, 2) construct validation and 3) criterion-related validation. The criterion-related validity involved expert review of the results from a comparison of the performance of six case studies. This research adds value to the field by offering a generalizable model and measurement system to compare performance of NSF science and engineering centers. It provides a new scoring method to compare and evaluate different IUCRCs. NSF center evaluators can then use these scores as a decision support tool for additional funding decisions and center managers can use these scores to analyze their portfolios in an objective, evidence-based manner increasing the achievement of their research objectives. The study effectively defined a set of output indicators painting a balanced-holistic picture of the NSF IUCRC program meeting the first objective of this research. While the generalizable model was only tested using the NSF IUCRC program, the model provides a new scoring method to compare and evaluate different IUCRCs in different programs.

A framework and metrics for evaluation was developed. Therefore, a new method for CRC performance comparison was introduced into the literature stream. This research begins to close the gap for cross CRC comparison by developing a generalizable model and a system for cross-center performance evaluation. The gap originally identified through literature was 
validated by experts. Gray agrees, "virtually all CRC outcome evaluation has been ad hoc, program-level evaluation studies" and that "these studies have tended to focus on technology transfer outcomes to industry"([43] p78).

\section{Application Contributions}

The next contribution follows as a result of the first by disseminating the model and results of the study for improved assessment in the NSF IUCRC program. This study tested the model and the method by evaluating six (6) alternative IUCRCs. Many studies question if the traditional bibliometric indicators are the "right ones" and caution that they paint a "partial picture"[78]. The results of this research provide supporting evidence to this stream of literature by finding that new methods contribute significantly higher towards knowledge and technology transfer objectives than licenses. Federally funded CRCs are required to have transparency in their decision making processes. This research provides a new method that highlights disagreements helping to drive discussions and transparent decision making processes.

Representatives for the NSF SciPSI program remarked through an evaluation of this research agree that "the need for understanding IUCRCs is important. They are a key policy lever used by the government to enhance translational research." "Evaluating such centers remains difficult and often subjective, yet federal science agencies continue to invest considerable resources in them." (NSF SciPHI program proposal evaluators)

This study benefits the research community by applying a flexible approach that combines qualitative and quantitative output indicators. Additional insight will be gained about the importance and use of output indicators. This holistic approach demonstrates a generalizable model that provides comparison among cooperative research centers.

\section{REFERENCES}

[1] C. Boardman and D. Gray, "The new science and engineering management: cooperative research centers as government policies, industry strategies, and organizations," J. Technol. Transf., vol. 35, pp. 445-459, 2010.

[2] C. Boardman and B. Bozeman, "Academic faculty as intellectual property in university-industry research alliances," Econ. Innov. New Technol., no. 2, pp. 1-18, 2015. 
[3] C. Boardman and B. Ponomariov, "A preliminary assessment of the potential for 'team science' in DOE Energy Innovation Hubs and Energy Frontier Research Centers," Energy Policy, vol. 39, no. 6, pp. 3033-3035, 2011.

[4] Y. S. Lee, "The Sustainability of University-Industry Research Collaboration," J. Technol. Transf., vol. 25, pp. 111-133, 2000.

[5] H. Etzkowitz and L. Leydesdorff, "The dynamics of innovation: from National Systems and 'Mode 2' to a Triple Helix of university-industry-government relations,' Res. Policy, vol. 29, no. 2, pp. 109-123, Feb. 2000.

[6] E. Carayannis, M. Del, G. Maria, R. Della, E. Carayannis, M. Del, G. Maria, R. Della, M. Villasalero, F. Campanella, M. Rosaria, D. Peruta, M. Del Giudice, and M. Villasalero, "Managing the intellectual capital within government-university-industry R\&D partnerships," J. Intellect.

Cap., vol. 15, no. 4, pp. 611-630, 2014.

[7] M. Perkmann, A. Neely, and K. Walsh, "How should firms evaluate success in university-industry alliances? A performance measurement system," R Manag., vol. 41, no. 2, pp. 202-216, 2011.

[8] B. Bozeman, D. Fay, and C. P. Slade, "Research collaboration in universities and academic entrepreneurship: The-state-of-the-art," J. Technol. Transf., vol. 38, pp. 1-67, 2013.

[9] D. O. Gray, O. Leonchuk, L. C. McGowen, and T. Michaelis, "2012-2013 Process Outcome Survey Results descriptive statistics compiled from industry and faculty surveys," Raleigh, North Carolina State University, 2014.

[10] D. O. Gray, D. Rivers, and G. Vermont, "Measuring the Economic Impacts of the NSF Industry / University Cooperative Research Centers Program : A Feasibility Study," Arlington, Virginia, 2012.

[11] E. Geisler, "Benchmarking inter-organisational technology cooperation: the link between infrastructure and sustained performance," Int. J. Technol. Manag., vol. 25, no. 8, pp. 675-702, 2003.

[12] M. Perkmann, A. Neely, and K. Walsh, "How should firms evaluate success in university-industry alliances? A performance measurement system: How should firms evaluate success in universityindustry alliances?," RD Manag., vol. 41, no. 2, pp. 202-216, Mar. 2011.

[13] B. Bozeman, D. Fay, and C. P. Slade, "Research collaboration in universities and academic entrepreneurship: the-state-of-the-art," J. Technol. Transf., vol. 38, no. 1, pp. 1-67, Feb. 2013.

[14] A. N. Link and D. S. Siegel, "University-based technology initiatives: Quantitative and qualitative evidence," Res. Policy, vol. 34, no. 3, pp. 253-257, Apr. 2005.

[15] P. H. Phan and D. S. Siegel, "The Effectiveness of University Technology Transfer," Found. Trends® Entrep., vol. 2, no. 2, pp. 77-144, 2006.

[16] D. O. Gray, O. Leonchuk, L. C. McGowen, and T. Michaelis, "2012-2013 Process Outcome Survey Results descriptive statistics compiled from industry and faculty surveys." Raleigh, North Carolina State University, 2014.

[17] H. Grupp and H. A. Linstone, "Around the Globe Resurrection and New Paradigms," Technol. Forecast. Soc. Change, vol. 94, pp. 85-94, 1999.

[18] P. Ecken, T. Gnatzy, and H. von der Gracht, "Desirability bias in foresight: Consequences for decision quality based on Delphi results," Technol. Forecast. Soc. Change, vol. 78, no. 9, pp. 1654-1670, Nov. 2011.

[19] Y. Yokoo and K. Okuwada, "Identifying expected areas of future innovation by combining foresight outputs," Foresight, vol. 15, no. 1, pp. 6-18, 2013.

[20] L. Georghiou and J. Cassingena Harper, "Rising to the challenges - Reflections on Future-oriented Technology Analysis," Technol. Forecast. Soc. Change, vol. 80, no. 3, pp. 467-470, Mar. 2013.

[21] E. Gibson, "Supporting Sustainable technology cluster development: a performance measurement problem," in PICMET 2015, 2015, pp. 1-16.

[22] B. Martin and R. Johnston, "Technology Foresight for Wiring Up the National Innovation System Experiences in Britain , Australia , and New Zealand," Technol. Forecast. Soc. Change, vol. 60, no. 1999, pp. 37-54, 1999. 
[23] F. W. Geels, "Ontologies, socio-technical transitions (to sustainability), and the multi-level perspective," Res. Policy, vol. 39, no. 4, pp. 495-510, May 2010.

[24] R. Rohrbeck, "Harnessing a network of experts for competitive advantage: technology scouting in the ICT industry," RD Manag., vol. 40, no. 2, pp. 169-180, Mar. 2010.

[25] R. Rohrbeck, L. Konnertz, and S. Knab, "Collaborative business modelling for systemic and sustainability innovations," Int. J. Technol. Manag., vol. 63, no. 1/2, p. 4, 2013.

[26] V. (Vic) Chavez, "Creative enterprise as a solution vector for twenty first century problems," Technol. Forecast. Soc. Change, vol. 80, no. 2, pp. 191-193, Feb. 2013.

[27] H. Masum, J. Ranck, and P. A. Singer, "Five promising methods for health foresight," Foresight, vol. 12, no. 1, pp. 54-66, Feb. 2010.

[28] F. Alkemade and R. A. A. Suurs, "Patterns of expectations for emerging sustainable technologies," Technol. Forecast. Soc. Change, vol. 79, no. 3, pp. 448-456, Mar. 2012.

[29] F. W. Geels, "From sectoral systems of innovation to socio-technical systems," Res. Policy, vol. 33, no. 6-7, pp. 897-920, Sep. 2004.

[30] J. D. Roessner, "Review of Progress in quantitative nondestructive evaluation," Rev. Prog. Quant. Nondestruct. Eval., vol. 12, pp. 31-39, 1998.

[31] A. N. Link and D. S. Siegel, "University-based technology initiatives: Quantitative and qualitative evidence," Res. Policy, vol. 34, no. 3, pp. 253-257, 2005.

[32] T. A. Tran, "Strategic Evaluation of University Knowledge and Technology Transfer Effectiveness," Portland State University, 2013.

[33] T. U. Daim, G. Rueda, H. Martin, and P. Gerdsri, "Forecasting emerging technologies: Use of bibliometrics and patent analysis," Technol. Forecast. Soc. Change, vol. 73, no. 8, pp. 981-1012, Oct. 2006.

[34] D. K. R. Robinson, L. Huang, Y. Guo, and A. L. Porter, "Forecasting Innovation Pathways (FIP) for new and emerging science and technologies," Technol. Forecast. Soc. Change, vol. 80, no. 2, pp. 267-285, Feb. 2013.

[35] E. G. Carayannis and M. von Zedtwitz, "Architecting gloCal (global-local), real-virtual incubator networks (G-RVINs) as catalysts and accelerators of entrepreneurship in transitioning and developing economies: lessons learned and best practices from current development and business incubation ," Technovation, vol. 25, no. 2, pp. 95-110, Feb. 2005.

[36] R. W. Smilor, D. V Gibson, and G. Kozmetsky, "Creating the Technopolis : High Technology Development in Austin , Texas," Bus. Ventur., pp. 49-67, 1989.

[37] J. Cunningham, P. O'Reilly, C. O'Kane, and V. Mangematin, "The inhibiting factors that principal investigators experience in leading publicly funded research," J. Technol. Transf., vol. 39, pp. 93110, 2014.

[38] D. O. Gray, L. Tornatzky, L. McGowen, and E. Sundrome, "Research Center Sustainability and Survival: Case Studies of Fidelity, Reinvention and Leadership of Industry/University Cooperative Research Centers," vol. 0631414, p. 93, 2012.

[39] D. O. Gray and S. G. Walters, Managing the industry/university cooperative research center : A guide for directors and other stakeholders. Columbus: Battelle Press, 1998.

[40] R. Rohrbeck and S. Kaab, "Collaborative business modelling for systemic and sustainability innovations," Int. J. Technol. Manag., vol. 63, no. 1/2, pp. 4-23, 2013.

[41] B. Bozeman, "Technology transfer and public policy: a review of research and theory," Res. Policy, vol. 29, pp. 627-655, 2000.

[42] D. O. Gray, C. Boardman, and D. Rivers, "The new science and engineering management: cooperative research centers as intermediary organizations for government policies and industry strategies," in Cooperative research centers and technical innovation, New York: Springer, 2013, pp. 3-33.

[43] D. O. Gray, "Making team science better: Applying improvement-oriented evaluation principles to evaluation of coorperative research centers," New Dir. Eval., no. 118, pp. 107-114, 2008.

[44] R. N. Kostoff, "Science and Technology Metrics," Arlington, Virginia, 2005. 
[45] M. H. Cragin, L. Nichols, M. Simon, and S. M. Watts, "Measuring science: Emerging tools for analysis of federal R\&D investments," Proc. ASIST Annu. Meet., vol. 49, no. 1, 2012.

[46] H. Etzkowitz and L. Leydesdorff, "The dynamics of innovation: from National Systems and 'Mode 2' to a Triple Helix of university-industry-government relations," Res. Policy, vol. 29, no. 2, pp. 109-123, Feb. 2000.

[47] R. Ruegg and I. Feller, A Toolkit for Evaluating Public R\&D Investment. Gaithersburd, MD: National Institute of Standards and Technology, NIST GCR 03-857, 2003.

[48] C. Chukumba and R. Jensen, "University Invention, Entrepreneurship, and Start-Ups," Natl. Bur. Econ. Res., 2005.

[49] T. R. Anderson, T. U. Daim, and F. F. Lavoie, "Measuring the efficiency of university technology transfer," Technovation, vol. 27, no. 5, pp. 306-318, May 2007.

[50] S. Shane and D. Somaya, "The effects of patent litigation on university licensing efforts," J. Econ. Behav. Organ., vol. 63, no. 4, pp. 739-755, Aug. 2007.

[51] S. Shane and D. Somaya, "The effects of patent litigation on university licensing efforts," J. Econ. Behav. Organ., vol. 63, pp. 739-755, 2007.

[52] B. Hall, A. Link, and J. Scott, "The Review of Economics and Statistics," Rev. Econ. Stat., vol. 85, no. 2, pp. 485-491, 2003.

[53] D. Hicks, "Performance-based university research funding systems," Res. Policy, vol. 41, no. 2, pp. 251-261, 2012.

[54] W. Cohen, R. Florida, and W. Goe, "University-Industry Research Centers in the United States." Center for Economic Development, H. John Heinz III School of Public Policy and Management, Carnegie Mellon University, 1994.

[55] W. M. Cohen, R. R. Nelson, and J. P. Walsh, "Links and Impacts: The Influence of Public Research on Industrial R\&D," Manag. Sci., vol. 48, no. June 2015, pp. 1-23, 2002.

[56] M. P. Feldman and M. R. Kelley, "The ex ante assessment of knowledge spillovers: Government R\&D policy, economic incentives and private firm behavior," Res. Policy, vol. 35, pp. 1509-1521, 2006.

[57] L. McGowan, "Program sustainability for cooperative research centers: A longitudinal analysis," North Carolina State University, 2012.

[58] J. C. Hayton, S. Sehili, and V. Scarpello, "Why do firms join consortial research centers? An empirical examination of firm, industry and environmental antecedents," J. Technol. Transf., vol. 35, pp. 494-510, 2010.

[59] NSF, "Industry \& University Cooperative Research Program (I/UCRC)," NSF 13-594, 2013. [Online]. Available: http://www.nsf.gov/pubs/2013/nsf13594/nsf13594.htm. [Accessed: 16-Feb2015].

[60] A. Abbasi, R. T. Wigand, and L. Hossain, "Measuring social capital through network analysis and its influence on individual performance," Libr. Inf. Sci. Res., vol. 36, no. 1, pp. 66-73, 2014.

[61] T. Penfield, M. J. Baker, R. Scoble, and M. C. Wykes, "Assessment, evaluations, and definitions of research impact: A review," Res. Eval., vol. 23, no. 1, pp. 21-32, 2014.

[62] White House Office of Management and Budget, "Science and Technology Priorities for the FY 2011 Budget," Memoranda 2009: M-09-27, 2011. [Online]. Available: www.whitehouse.gov/omb/memoranda_2009. [Accessed: 16-Feb-2015].

[63] D. O. Gray and H. J. Steenhuis, "Quantifying the benefits of participating in an industry university research center: An examination of research cost avoidance," Scientometrics, vol. 58, no. 2, pp. 281-300, 2003.

[64] E. A. Corley, P. C. Boardman, and B. Bozeman, "Design and the management of multiinstitutional research collaborations: Theoretical implications from two case studies," Res. Policy, vol. 35, pp. 975-993, 2006.

[65] J. Ramanathan, R. Ramnath, M. J. Herold, and B. J. R. Wierwille, "An agile translation process for complex innovations: An industry/university cooperative research center case study," Proc. Front. Educ. Conf. FIE, pp. 1532-1538, 2013. 
[66] C. S. Scott, Compendium 2014. Raleigh, N.C.: NSF, 2014.

[67] J. Bruneel, P. D'Este, and A. Salter, "Investigating the factors that diminish the barriers to university-industry collaboration," Res. Policy, vol. 39, no. 7, pp. 858-868, 2010.

[68] D. Roessner, L. Manrique, and J. Park, "The economic impact of engineering research centers: preliminary results of a pilot study," J. Technol. Transf., vol. 35, pp. 475-493, 2010.

[69] U. Schmoch, T. Schubert, D. Jansen, R. Heidler, and R. von Görtz, "How to use indicators to measure scientific performance: a balanced approach," Res. Eval., vol. 19, no. 1, pp. 2-18, 2010.

[70] D. Palomares-Montero and a. Garcia-Aracil, "What are the key indicators for evaluating the activities of universities?," Res. Eval., vol. 20, no. 5, pp. 353-363, 2011.

[71] L. I. Schultz, "Measuring the Activities of Collaborative Research Centers," Proc. 17th Int. Conf. Sci. Technol. Indic., vol. 2, pp. 743-755, 2012.

[72] R. Ruegg, "Bridging from Project Case Study to Portfolio Analysis in a Public R \& D Program, NIST GCR 06-891," Gaithersburg, MD, 2006.

[73] R. Adner and R. Kapoor, "Value creation in innovation ecosystems: how the structure of technological interdependence affects firm performance in new technology generations," Strateg. Manag. J., vol. 31, pp. 306-333, 2010.

[74] T. Wallner and M. Menrad, "Extending the innovation ecosystem," Proc. IXXII ISPIM Conf. Hamburd Ger., pp. 1 - 9, 2004.

[75] R. Graham, "Technology Innovation Ecosystem Benchmarking Study : Key findings from Phase $1, " 2013$.

[76] C. Freeman and L. Soete, "Developing science, technology and innovation indicators: What we can learn from the past," Res. Policy, vol. 38, no. 4, pp. 583-589, May 2009.

[77] Y. Motoyama, J. Konczal, J. Bell-masterson, and A. Morelix, "Think Locally, Act Locally: Building a Robust Entrepreneurial Ecosystem," 2014.

[78] C. S. Wagner, J. D. Roessner, K. Bobb, J. T. Klein, K. W. Boyack, J. Keyton, I. Rafols, and K. Börner, "Approaches to understanding and measuring interdisciplinary scientific research (IDR): A review of the literature," J. Informetr., vol. 5, pp. 14-26, 2011.

[79] J. D. Adams, E. P. Chiang, and K. Starkey, "Industry-University Cooperative Research Centers," J. Technol. Transf., vol. 26, pp. 73-86, 2001.

[80] A. Abbasi, K. S. K. Chung, and L. Hossain, "Egocentric analysis of co-authorship network structure, position and performance," Inf. Process. Manag., vol. 48, no. 4, pp. 671-679, 2012.

[81] T. R. Anderson, T. U. Daim, and F. F. Lavoie, "Measuring the efficiency of university technology transfer," Technovation, vol. 27, no. 5, pp. 306-318, May 2007.

[82] A. Geuna and A. Muscio, "The governance of university knowledge transfer: A critical review of the literature," Minerva, vol. 47, pp. 93-114, 2009.

[83] R. E. Quinn and J. Rohrbaugh, "A Spatial Model of Effectiveness Criteria : Towards a Competing Values Approach to Organizational Analysis," Manag. Sci., vol. 29, no. 3, pp. 363-377, 2014.

[84] R. M. Steers, "Problems in the Measurement of Organizational Effectiveness," Adm. Sci. Sci., vol. 10, no. 4, pp. 546-558, 1975.

[85] K. Cameron, "Measuring Organizational Effectiveness in Institutions of Higher Education," Adm. Sci. Q., vol. 23, no. December, pp. 604-632, 1978.

[86] R. E. Quinn, J. Rohrbaugh, and J. Rohrbaugh, "A competing values approach to organizational effectiveness," Public Product. Rev., vol. 5, no. 2, pp. 122-140, 1981.

[87] K. Phan, "Innovation Measurement: A Decision Framework to Determine Innovativeness of a Company," Portland State University, 2013.

[88] H. Chen and D. F. Kocaoglu, "A sensitivity analysis algorithm for hierarchical decision models," Eur. J. Oper. Res., vol. 185, pp. 266-288, 2008.

[89] J. L. Mumpower and T. R. Stewart, "Expert Judgement and Expert Disagreement," Think. Reason., vol. 2, no. February 2015, pp. 191-212, 1996.

[90] D. I. Cleland and D. F. Kocaoglu, Engineering Management. New York: McGraw-Hill, 1981. 
[91] T. L. Saaty, "Decision making with the analytic hierarchy process," Int. J. Serv. Sci., vol. 1, no. 1, p. 83, 2008.

[92] R. P. Hämäläinen and R. Karjalainen, "Decision support for risk analysis in energy policy," Eur. J. Oper. Res., vol. 56, no. 2, pp. 172-183, Jan. 1992.

[93] P. Gerdsri and D. F. Kocaoglu, "HDM for developing national emerging technology strategy and policy supporting sustainable economy: A case study of nanotechnology for Thailand\&\#x2019;s agriculture," in PICMET '08 - 2008 Portland International Conference on Management of Engineering \& Technology, Cape Town, South Africa, 2008, pp. 344-350.

[94] F. Elkarmi and I. Mustafa, "Increasing the utilization of solar energy technologies (SET) in Jordan," Energy Policy, vol. 21, no. 9, pp. 978-984, Sep. 1993.

[95] S. K. Lee, Y. J. Yoon, and J. W. Kim, "A study on making a long-term improvement in the national energy efficiency and GHG control plans by the AHP approach," Energy Policy, vol. 35, no. 5, pp. 2862-2868, May 2007.

[96] S. K. Lee, G. Mogi, and J. W. Kim, "The competitiveness of Korea as a developer of hydrogen energy technology: The AHP approach,” Energy Policy, vol. 36, pp. 1284-1291, 2008.

[97] H. Chen and D. F. Kocaoglu, "A sensitivity analysis algorithm for hierarchical decision models," Eur. J. Oper. Res., vol. 185, no. 1, pp. 266-288, Feb. 2008.

[98] E. Sundstrom and D. O. Gray, "Fostering Team Science: Innovative leadership practices in NSF Industry/University Research Cooperative Centers," in Triple Helix VIII: International Conference on Government, University \& Industry Linkages, 2010, no. October, pp. 20-22.

[99] D. Gray, E. Sundstrom, L. G. Tornatzky, and L. McGowen, "When Triple Helix unravels: A multi-case analysis of failures in industry-university cooperative research centres," Ind. High. Educ., vol. 25, no. 5, pp. 333-345, 2011.

[100] T. R. Behrens and D. O. Gray, "Unintended consequences of cooperative research: Impact of industry sponsorship on climate for academic freedom and other graduate student outcome," Res. Policy, vol. 30, pp. 179-199, 2001.

[101] A. Comacchio, S. Bonesso, and C. Pizzi, "Boundary spanning between industry and university: the role of Technology Transfer Centres," J. Technol. Transf., vol. 37, no. 6, pp. 943-966, Aug. 2011.

[102] M. P. Feldman and M. R. Kelley, "The ex ante assessment of knowledge spillovers: Government R\&D policy, economic incentives and private firm behavior," Res. Policy, vol. 35, pp. 1509-1521, 2006.

[103] M. Devine, T. James, and T. Adams, "Government supported industry-university research centers: Issues for successful technology transfer," J. Technol. Transf., vol. 12, no. 1, pp. 27-37, 1987.

[104] E. Piva and C. Rossi-Lamastra, "Systems of indicators to evaluate the performance of universityindustry alliances: a review of the literature and directions for future research," Meas. Bus. Excell., vol. 17, no. June, pp. 40-54, 2013.

[105] M. Gaughan and E. Corley, "Science faculty at US research universities: The impacts of university research center-affiliation and gender on industrial activities," Technovation, vol. 30, no. 3, pp. 215-222, 2010.

[106] P. C. Boardman and E. A. Corley, "University research centers and the composition of research collaborations," Res. Policy, vol. 37, no. 2, pp. 900-913, 2008.

[107] B. L. Ponomariov and P. C. Boardman, "Influencing scientists' collaboration and productivity patterns through new institutions: University research centers and scientific and technical human capital," Res. Policy, vol. 39, no. 5, pp. 613-624, 2010.

[108] E. Geisler, "Measuring the Contributions of Knowledge Management Systems To the Strategic Competitiveness of Organizations: a Review and a Model," Int. J. Innov. Technol. Manag., vol. 07, no. 02, pp. 89-107, 2010.

[109] M. Perkmann, V. Tartari, M. McKelvey, E. Autio, A. Broström, P. D’Este, R. Fini, A. Geuna, R. Grimaldi, A. Hughes, S. Krabel, M. Kitson, P. Llerena, F. Lissoni, A. Salter, and M. Sobrero, "Academic engagement and commercialisation: A review of the literature on university-industry relations," Res. Policy, vol. 42, no. 2, pp. 423-442, 2013. 
[110] E. Carayannis, M. Del, G. Maria, R. Della, E. Carayannis, M. Del, G. Maria, R. Della, M. Villasalero, F. Campanella, M. Rosaria, D. Peruta, M. Del Giudice, and M. Villasalero, "Managing the intellectual capital within government-university-industry R\&D partnerships," J. Intellect. Cap., vol. 15, no. 4, pp. 611-630, 2014.

[111] H. Etzkowitz, "The norms of entrepreneurial science: cognitive effects of the new universityindustry linkages," Res. Policy, vol. 27, pp. 823-833, 1998.

[112] D. Rivers, "To Join or Not to Join: Individual and Sub-organizational Factors Affecting Industry Membership in University-based Cooperative Research Centers," 8th Int. Triple Helix Conf., 2010.

[113] W. Tsai, "Knowledge Transfer in Intraorganizational Networks : Effects of Network Position and Absorptive Capacity on Business Unit Innovation and Performance," Acad. Manage. J., vol. 44, no. 5, pp. 996-1004, 2015.

[114] D. Gray, M. Lindblad, and J. Rudolph, "Industry-University Research Centers: A Multivariate Analysis of Member Retention," J. Technol. Transf., vol. 26, pp. 247-254, 2001.

[115] J. E. Tyler, "Redeploying Bayh-Dole: Beyond Merely doing good to optimizing the potential in results of taxpayer-funded research," J. Technol. Transf., vol. 38, pp. 911-929, 2013.

[116] J. D. Rogers and B. Bozeman, "Basic research and the success of federal lab-industry partnerships," J. Technol. Transf., vol. 22, no. 3, pp. 37-47, 1997.

[117] B. Bozeman and C. Boardman, "Academic Faculty in University Research Centers: Neither Capitalism's Slaves nor Teaching Fugitives," J. High. Educ., vol. 84, no. 1, pp. 88-120, 2013.

[118] M. Perkmann and K. Walsh, "University-industry relationships and open innovation: Towards a research agenda," Int. J. Manag. Rev., vol. 9, no. 4, pp. 259-280, 2007.

[119] J. S. Katz and B. R. Martin, "What is research collaboration?," Res. Policy, vol. 26, no. 1, pp. 1$18,1997$.

[120] S. Chai and W. Shih, "Bridging science and technology through academic-industry partnerships," Res. Policy, vol. 45, no. 1, pp. 148-158, 2016.

[121] Roessner, "Outcomes and Impacts of the State / Industry- University Cooperative Research Centers ( S / Iucrc ) Program," 2000.

[122] D. Gray, D. Rivers, L. McGowen, L. Leonchuck, and T. Michaelis, "SBIR/STTR Supplemental Opportunity in I/UCRCs," Arlington, Virginia, 2014.

[123] D. S. Siegel, D. A. Waldman, L. E. Atwater, and A. N. Link, "Toward a model of the effective transfer of scientific knowledge from academicians to practitioners: qualitative evidence from the commercialization of university technologies," J. Eng. Technol. Manag., vol. 21, no. 1-2, pp. 115142, 2004.

[124] M. Balconi and A. Laboranti, "University-industry interactions in applied research: The case of microelectronics," Res. Policy, vol. 35, pp. 1616-1630, 2006.

[125] A. Abbasi and J. Altmann, "On the Correlation between Research Performance and Social Network Analysis Measures Applied to Research Collaboration Networks," 2011 44th Hawaii Int. Conf. Syst. Sci., pp. 1-10, 2011.

[126] E. Y. Li, C. H. Liao, and H. R. Yen, "Co-authorship networks and research impact: A social capital perspective," Res. Policy, vol. 42, no. 9, pp. 1515-1530, 2013.

[127] Y. Motoyama, J. Konczal, J. Bell-masterson, and A. Morelix, "Think Locally, Act Locally : Building a Robust Entrepreneurial Ecosystem," 2014

[128] I. Rafols, A. L. Porter, and L. Leydesdorff, "Science overlay maps: a new tool for research policy and library management," J. Am. Soc. Inf. Sci. Technol., vol. 61, no. 9, pp. 1871-1887, 2009.

[129] L. Leydesdorff, S. Carley, and I. Rafols, "Global maps of science based on the new Web-ofScience categories," Scientometrics, vol. 94, no. 2, pp. 589-593, 2013.

[130] A. L. Porter and I. Rafols, "Is science becoming more interdisciplinary? Measuring and mapping six research fields over time," Scientometrics, vol. 81, no. 3, pp. 719-745, 2009.

[131] J. G. Garner, A. L. Porter, N. C. Newman, and T. a. Crowl, "Assessing research network and disciplinary engagement changes induced by an NSF program,” Res. Eval., vol. 21, no. 2, pp. 89104, 2012. 
[132] T. A. Tran, "Strategic Evaluation of University Knowledge and Technology Transfer Effectiveness," Portland State University, 2013

[133] I. Iskin, "An Assessment Model for Energy Efficiency Program Planning in Electric Utilities: Case of Northwest U.S.," Portland State University, 2014.

[134] J. Wallenius, J. S. Dyer, P. C. Fishburn, R. E. Steuer, S. Zionts, K. Deb, J. S. Dyer, P. C. Fishburn, and R. E. Steuer, "Multiple Criteria Decision Making, Multiattribute Utility Theory : Recent Accomplishments and What Lies Ahead Multiple Criteria Decision Making, Multiattribute Utility Theory : Recent Accomplishments and What Lies Ahead,” Manage. Sci., no. June 2016, 2008.

APPENDICES

\section{Appendix 1 Expert Background}




\begin{tabular}{|c|c|c|c|}
\hline Expert \# & Affiliation & Title & Background \\
\hline 1 & NSF Program & NSF Program Manager & NSF \\
\hline 2 & North Carolina State U & Professor/Director & $\mathrm{C}$ \\
\hline 3 & Ohio State U & Professor & $\mathrm{R}$ \\
\hline 4 & NSF IUCRC & NSF Project Manager & $\mathrm{R}$ \\
\hline 5 & NSF Consultant & Evaluator IUCRC & $\mathrm{R}$ \\
\hline 6 & Iowa State & Assoc. Prof/Evaluator & NSF \\
\hline 7 & University of Washington & Professor/Evaluator & $\mathrm{R}$ \\
\hline 8 & Palo Alto & Assoc. Prof/Evaluator & NSF \\
\hline 9 & U of California, Berkeley & Professor/Director & $\mathrm{C}$ \\
\hline 10 & University of Florida & Evaluator IUCRC & NSF \\
\hline 11 & Grand Valley state U & VP/Evaluator & $\mathrm{R}$ \\
\hline 12 & $\mathrm{U}$ of Colorado, Boulder & CoDirector IUCRC & $\mathrm{C}$ \\
\hline 13 & North Carolina State U & Director IUCRC & $\mathrm{C}$ \\
\hline 15 & SUNY Buffalo & Director IUCRC & $\mathrm{C}$ \\
\hline 16 & Arizona State U & IUCRC staff & $\mathrm{C}$ \\
\hline 17 & Univ of Bufalo & Director IUCRC & $\mathrm{C}$ \\
\hline 18 & U of Arizona & Director IUCRC & $\mathrm{C}$ \\
\hline 19 & Virginia Tech & Director IUCRC & $\mathrm{C}$ \\
\hline 20 & Oregon State Univ & Director IUCRC & $\mathrm{C}$ \\
\hline 21 & Virginia Tech & Director IUCRC & $\mathrm{C}$ \\
\hline 22 & UC Davis & Director IUCRC & $\mathrm{C}$ \\
\hline 23 & Brigham Young Univ & Director IUCRC & $\mathrm{C}$ \\
\hline 24 & U of Arkansas & Director IUCRC & $\mathrm{C}$ \\
\hline 25 & U of Tennessee, Knoxville & CoDirector IUCRC & $\mathrm{C}$ \\
\hline 26 & U of California, Santa-Cruz & Center Executive & $\mathrm{C}$ \\
\hline 27 & Boise State & Evaluator IUCRC & NSF \\
\hline 28 & North Texas & Professor/Assoc Director & $\mathrm{C}$ \\
\hline 29 & Georgetown U & Director IUCRC & $\mathrm{C}$ \\
\hline 30 & U of Washington & Director IUCRC & $\mathrm{C}$ \\
\hline 31 & University of Tennessee & Evaluator IUCRC & NSF \\
\hline 32 & Purdue U & Professor/Evaluator & NSF \\
\hline 33 & George Washington U & Professor & $\mathrm{R}$ \\
\hline 34 & Arizona State U & Professor & $\mathrm{R}$ \\
\hline 35 & Univ of Georgia & Evaluator IUCRC & NSF \\
\hline 36 & Clarkson U & Director IUCRC & $\mathrm{C}$ \\
\hline 37 & Purdue U & Ass Prof/Assist. Dir & $\mathrm{C}$ \\
\hline
\end{tabular}

\section{Appendix 2 Desirability Curves}

Metrics and desirability curves are presented relative to each of the six goals. Figures below show the respective desirability curves. 
Desirability curves for new knowledge outputs

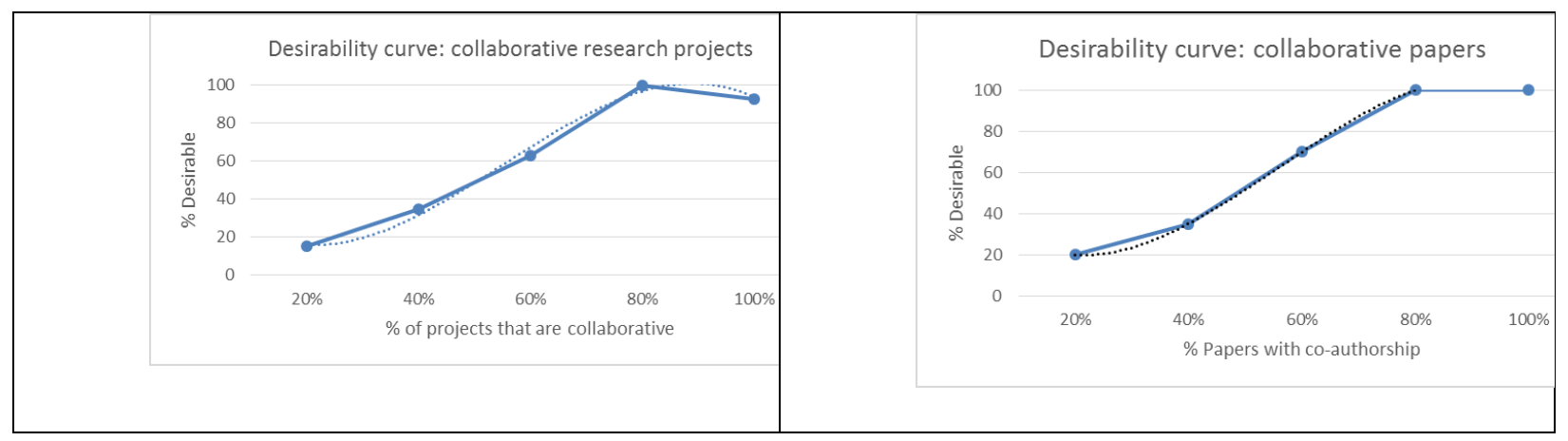

\section{Desirability curves for stakeholder satisfaction outputs}

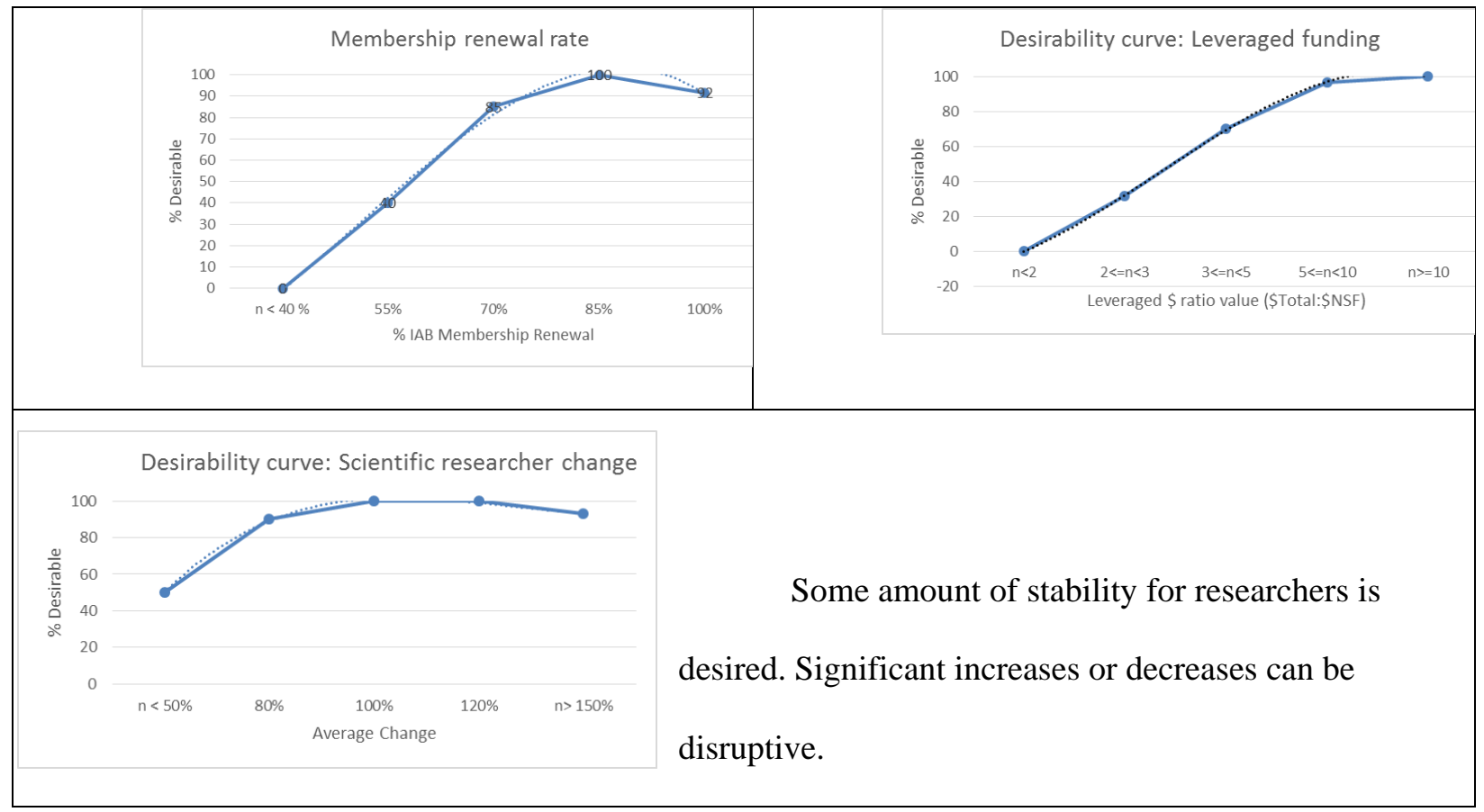

\section{Desirability curves for student involvement outputs}




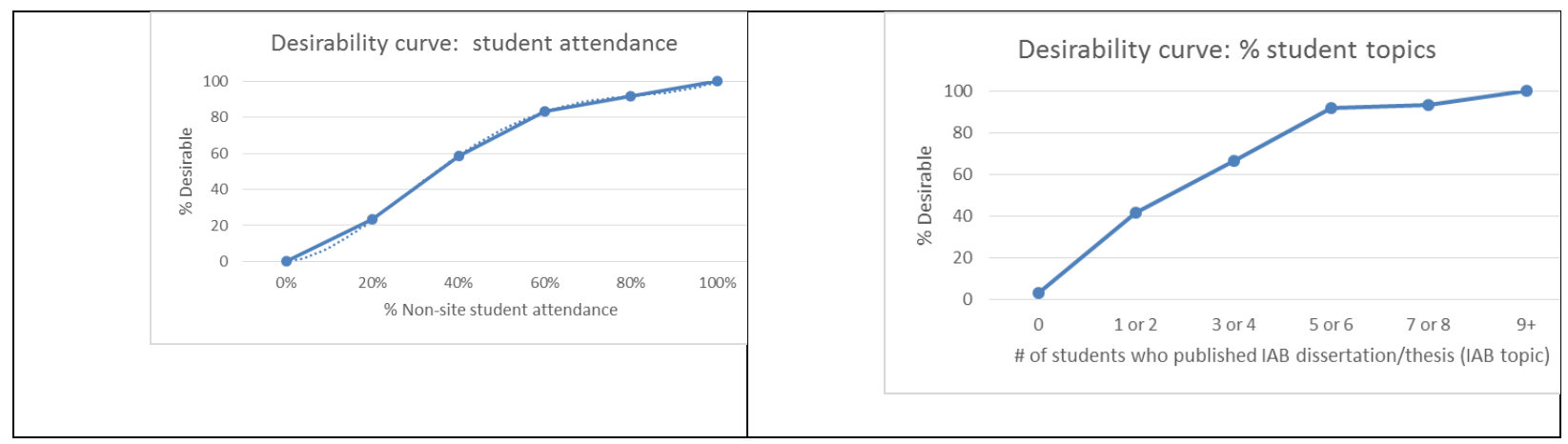

\section{Desirability curves for student development outputs}

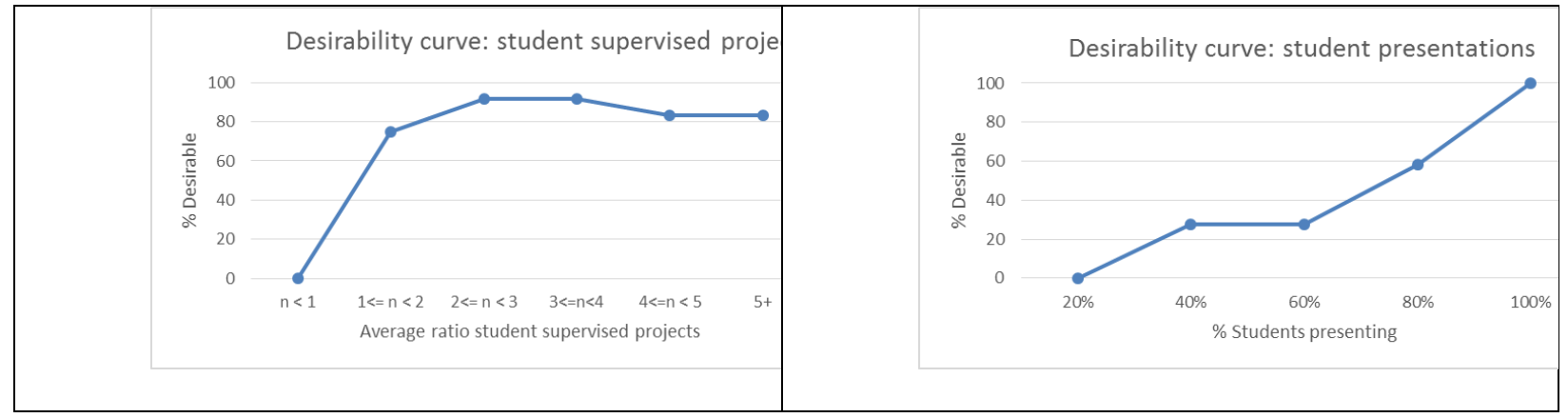

\section{Desirability curves for KTT media}

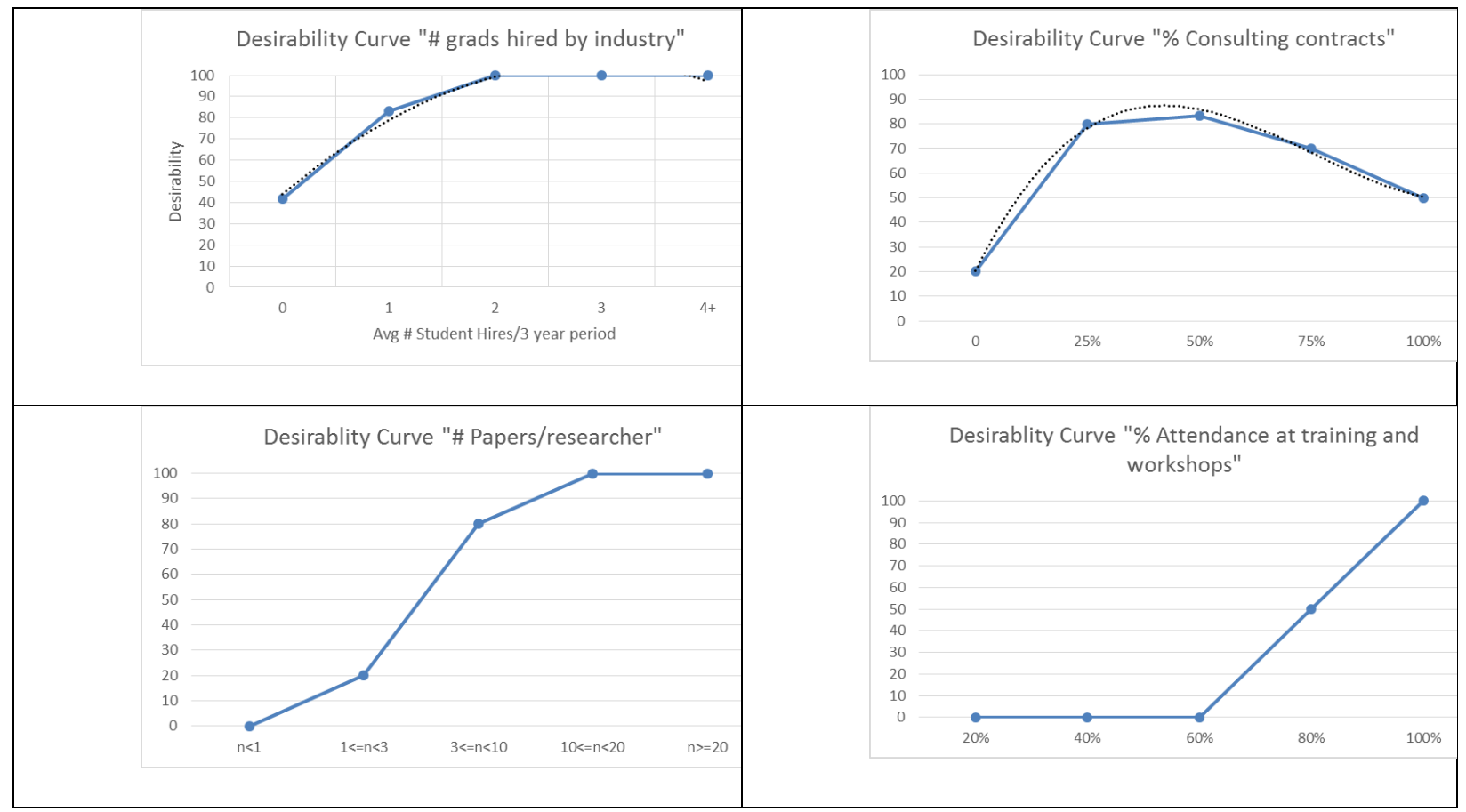

\section{Desirability curves for KTT object outputs}




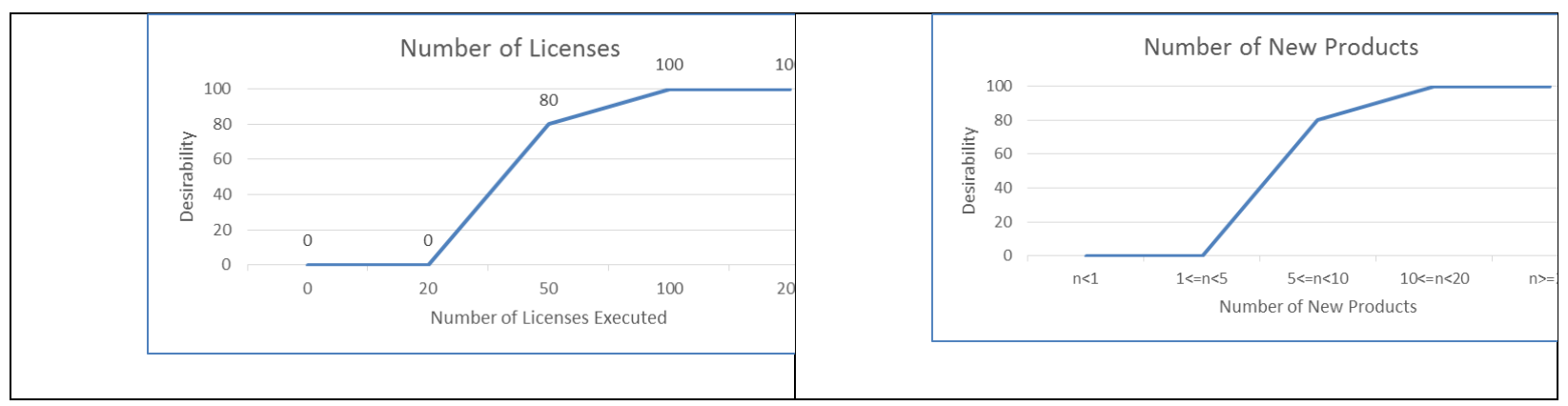

\section{Appendix 3 Additional Center Analyses}

\begin{tabular}{|c|c|c|c|c|c|c|}
\hline \multirow[t]{2}{*}{ Center } & \multirow{2}{*}{$\begin{array}{l}\text { Pre- } \\
\text { Score }\end{array}$} & \multirow[t]{2}{*}{$c_{j}$} & \multirow[t]{2}{*}{ Suggested Improvement } & \multicolumn{2}{|c|}{ Contribution } & \multirow{2}{*}{$\begin{array}{ll}\text { New } \\
\text { Score }\end{array}$} \\
\hline & & & & Current & Impact & \\
\hline \multirow[t]{2}{*}{$\mathrm{Ma}^{2} \mathrm{JIC}$} & \multirow[t]{2}{*}{0.68} & 1 & $\begin{array}{l}\text { Increase multi-site/multi-discipline research } \\
\text { project configurations from } 7 \text { to } 14 \text { of } 25 \text {. }\end{array}$ & 0.05 & +.04 & \multirow[t]{2}{*}{0.76} \\
\hline & & 2 & Increase co-publications from 5 to 9 of 15. & 0.02 & +.04 & \\
\hline \multirow[t]{2}{*}{ CPD } & \multirow[t]{2}{*}{0.56} & 1 & $\begin{array}{l}\text { Increase multi-site/multi discipline research } \\
\text { projects from } 0 \text { to } 5 \text { of } 12 \text {. }\end{array}$ & 0.02 & +.06 & \multirow[t]{2}{*}{0.64} \\
\hline & & 2 & $\begin{array}{l}\text { Support student interest in selecting IUCRC } \\
\text { topics for dissertation or thesis by } 2 \text { students }\end{array}$ & .06 & +.02 & \\
\hline $\mathrm{S}^{2} \mathrm{ERC}$ & 0.57 & 1 & $\begin{array}{l}\text { Increase multi-site/multi-discipline research } \\
\text { project configurations. Currently with } 0 \text { of } 22 \\
\text { they should increase to } 50 \% \text { multi-site or } \\
\text { multi-disciplined research project teams. }\end{array}$ & .02 & +.06 & 0.63 \\
\hline \multirow[t]{2}{*}{ CSR } & \multirow[t]{2}{*}{0.46} & 1 & $\begin{array}{l}\text { Encourage } 1 \text { student to select an IAB } \\
\text { research project as their dissertation or thesis } \\
\text { topic. }\end{array}$ & 0 & +.05 & \multirow[t]{2}{*}{0.58} \\
\hline & & 2 & $\begin{array}{l}\text { Increase collaborative configuration from } 0 \\
\text { to } 6 \text { of nine projects. Increase to } 60 \% \text {. }\end{array}$ & .02 & +.06 & \\
\hline \multirow[t]{2}{*}{ WEP } & \multirow[t]{2}{*}{0.46} & 1 & $\begin{array}{l}\text { Encourage } 1 \text { student to select an IAB } \\
\text { research project as their dissertation or thesis } \\
\text { topic. }\end{array}$ & 0 & +.05 & \multirow[t]{2}{*}{0.57} \\
\hline & & 2 & $\begin{array}{l}\text { Increase collaborative configuration from } 0 \\
\text { to } 0 \text { of } 11 \text { projects. Increase to } 60 \% \text {. }\end{array}$ & .02 & +.06 & \\
\hline \multirow[t]{2}{*}{ WBC } & \multirow[t]{2}{*}{0.55} & 1 & $\begin{array}{l}\text { Encourage } 1 \text { student to select an IAB } \\
\text { research project as their dissertation or thesis } \\
\text { topic. }\end{array}$ & 0 & +.05 & \multirow[t]{2}{*}{0.65} \\
\hline & & 2 & Projects $4 / 14$ increase to $70 \%$. & .05 & +.05 & \\
\hline
\end{tabular}

